\title{
THE PERMISSIBLE SCOPE OF HEARINGS, DISCOVERY, AND ADDITIONAL FACT- FINDING DURING JUDICIAL REVIEW OF INFORMAL AGENCY ACTION
}

\author{
Richard McMmlan, JR.* AND Todd D. Peterson**
}

The past ten years have witnessed a substantial growth in litigation challenging the informal decisionmaking of federal agencies. Judicial review of informal ${ }^{1}$ agency action under the Administrative Procedure Act (APA) or similar legislation ${ }^{2}$ is ordinarily carried out on the basis of the administrative record compiled before the agency decisionmaker. Although commentators liave written at length about wliat the administrative record should contain, ${ }^{3}$ little has been written about what other facts inay be put before the court in litigation challenging agency action. In the practical world of litigating against the government, two issues repeatedly arise: (1) what is the appropriate scope of discovery when judicial review is based on an administrative record; and (2) to what extent should a court liear evidence outside the administrative record in deciding the inerits of the case.

The Supreme Court has made it clear, beginning with Citizens to Preserve Overton Park, Inc. v. Volpe, ${ }^{4}$ that in most cases there will be a simple answer to these questions: courts should not permit additional factfinding beyond the administrative record. Courts have applied this presumption to the whole range of lawsuits against federal agencies -

* Partner, Crowell \& Moring, Washington, D.C.; Princeton University (A.B., 1966); University of Minnesota (J.D., 1972); Board of Editors, Minnesota Law Review, 1971-72.

** Associate, Crowell \& Moring, Washington, D.C.; Brown University (A.B., 1973); University of Michigan (J.D., Summe Cum Laude, 1976); Note Editor, Michigan Law Review, 1975-76.

1. Infornal, as distinguished from fornal, agency action may fall into one of two categories: a) inforinal notice and comment rulemaking that does not require an agency hearing on the record within the meaning of 5 U.S.C. $\$ \S 556-557$ (1976 \& Supp. IV 1980), or b) nonrulemaking agency action taken without a formal trial-type hearing, see, e.g., Citizens to Preserve Overton Park, Inc. v. Volpe, 401 U.S. 402, 407-09 (1971).

2. The judicial review provisions of the Administrative Procedure Act, 5 U.S.C. $\$ \S 701-706$ (1976), often serve as a model for judicial review provisions in other statutes. See, e.g., Surface Mining Control and Reclamation Act of 1977 \$ 526, 30 U.S.C. $\$ 1276$ (Supp. IV 1980).

3. E.g., DeLong, Informal Rulemaking and the Integration of Law and Policy, 65 VA. L. REv. 257 (1979), and articles cited at id. 260 n.22.

4. 401 U.S. 402 (1971). 
from those involving rulemaking to those involving less formal decisions based on scant administrative records. Discovery or a hearing is available in these cases only under certain specific exceptions to the general rule.

Nevertheless the hist of these specific exceptions is growing; some form of discovery or factfinding is no longer uncommon in administrative record cases. In crafting the specific exceptions, however, courts generally have responded to the narrow facts of the particular dispute before the court. This approach has contributed to a considerable divergence of views among the courts about when discovery should be granted and when the presentation of evidence should be allowed. For example, although many courts have routmely denied all diseovery requests, other courts have granted discovery for the purposes of verifymg the completeness of the administrative record, 5 obtaining further explanation of the agency's decision, ${ }^{6}$ determining the reasons for delay im an agency's decisionmaking process, ${ }^{7}$ determining whether all relevant factors were considered by the decisionmaker, ${ }^{8}$ identifying materials relevant to the agency's contemporaneous construction of relevant regulations, ${ }^{9}$ determining whether the agency decision was affected by improper congressional influence, ${ }^{10}$ and identifying oral or other contacts between agency decisionmakers and other federal agencies. ${ }^{11}$

Moreover, even when additional factinding is deemed appropriate, courts often have had difficulty deciding on the type of factinding that should be permitted in a given case. For example, a private hitigant often asserts that the agency has failed to explain adequately the basis for its decision in the administrative record. The litigant inay seek discovery or the opportunity for a hearing to obtain further explanation from the agency decisionmakers. Courts have responded to such requests in a variety of ways, ${ }^{12}$ such as by remanding to the agency for further explanation; ${ }^{13}$ conductimg an evidentiary hearing; ${ }^{14}$ requesting

5. See Tenneco Oil Co. v. DOE, 475 F. Supp. 299, 317-18 (D. Del. 1979).

6. See A.O. Snrith Corp. v. FTC, 403 F. Supp. 1000, 1012-13 (D. Del. 1975).

7. See Abbott Laboratories, Inc. v. Harris, 481 F. Supp. 74, 77-78 (N.D. Ill. 1979).

8. See ASARCO, Inc. v. EPA, 616 F.2d 1153, 1160 (9th Cir. 1980); County of Suffolk v. Secretary of Interior, 562 F.2d 1368 (2d Cir. 1977), cert. denied, 434 U.S. 1064 (1978).

9. See Tenneco Oil Co. v. DOE, 475 F. Supp. 299, 318-19 (D. Del. 1979); Gulf Oil Corp. v. Schlesinger, 465 F. Supp. 913, 916 (E.D. Pa. 1979).

10. See Texas Medical Ass'n v. Mathews, 408 F. Supp. 303, 304-05 (W.D. Tex. 1976).

11. See Shell Oil Co. v. DOE, No. 79-134, slip op., (D. Del. May 31, 1979).

12. In soine cases the court simply holds that no additional explanation is required. See, e.g., Madison County Bldg. \& Loan Ass'n v. Federal Hoine Loan Bank Bd., 622 F.2d 393 (8th Cir. 1980).

13. See City Fed. Sav. and Loan Ass'n v. Federal Home Loan Bank Bd., 600 F.2d 681 (7th Cir. 1979).

14. See Citizens to Preserve Overton Park, Inc. v. Volpe, 401 U.S. 402, 420-21 (1971); Na- 
an affidavit from the agency to explain the decision; ${ }^{15}$ or permitting limited discovery. ${ }^{16}$

The diversity of approaches ${ }^{17}$ makes general rules governing the scope of supplemental factinding during judicial review of administrative action difficult to formulate. Numerous courts have ruled on the scope and timing of supplemental factfinding, yet no single court or commentator has provided useful rules of general applicability. This article attempts to fill this void by answering the recurrent questions: when should discovery be permitted and when should courts accept supplemental evidence beyond the administrative record.

In addressing these questions, this article first discusses the seminal Supreme Court cases of Citizens to Preserve Overton Park, Inc. $v$. Volpe ${ }^{18}$ and Camp v. Pitts. ${ }^{19}$ The article then identifies four categories of cases in which discovery, a hearing, or other fact-finding procedures may be appropriate. Finally, the article addresses the inevitable problems of governmental privilege that arise when discovery or a hearing is granted.

\section{The Substantive Law Background: Overton Park AND CAMP V. PITTS}

Prior to 1970 judicial review of agency decisionmaking ordinarily focused on agency rulemaking or formal agency adjudication. ${ }^{20} \mathrm{Re}-$ view of informal agency action not based on a rulemaking or formal adjudicatory record was relatively rare, and requests for discovery or for a hearing in those cases were equally rare. Beginning in the late 1960 s, however, a number of changes in different areas of administrative law combimed to broaden greatly the types of lawsuits that could be brought against federal agencies. In a series of important cases, the Supreme Court broadened the notion of standing, ${ }^{21}$ relaxed the stan-

tional Nutritional Foods Ass'n v. Weinberger, 512 F.2d 688 (2d Cir.), cert. denied, 423 U.S. 827 (1975).

15. Sce National Nutritional Foods Ass'n v. Mathews, 418 F. Supp. 394 (S.D.N.Y. 1976), rev'd on other grounds, 557 F.2d 325 (2d Cir. 1977).

16. See A.O. Smith Corp. v. FTC, 403 F. Supp. 1000 (D. Del. 1975).

17. See notes 110-24 infra and accompanying text.

18. 401 U.S. 402 (1971).

19. 411 U.S. 138 (1973).

20. The APA governs formal rulemaking, see 5 U.S.C. $\$ \S 553,556,557$ (1976); informal rulemaking, see 5 U.S.C. $\$ 553$ (1976); and formal adjudication, see 5 U.S.C. $\$ \S 554-557$ (1976).

21. See, eg., Association of Data Processing Serv. Orgs., Inc. v. Camp, 397 U.S. 150 (1970); Barlow v. Collins, 397 U.S. 159 (1970); see also Davis, The Liberalized Law of Standing, 37 U. CHI. L. REv. 450 (1970); Jaffe, Standing Again, 84 HARv. L. REv. 633 (1971). 
dards for ripeness, ${ }^{22}$ and expanded the types of cases appropriate for preenforcement review. ${ }^{23}$ At the same time, Congress amended the APA to waive the sovereign-immunity defense in suits against the government. ${ }^{24}$

These changes led increasingly to judicial challenges of agency decisions that were not based on a formal record. These suits were ordinarily brought under the APA, or some similar statute, in the district courts rather than in the courts of appeals. In many cases, hitigants sought to use the various pretrial discovery procedures and trial rights that district courts traditionally afford. The government typically opposed discovery or hearing rights by arguing that under the APA a court may not look beyond the inforination that the agency decisionmaker considered. ${ }^{25}$

The Supreme Court first addressed these competing contentions in Citizens to Preserve Overton Park, Inc. v. Volpe ${ }^{26}$ and Camp v. Pitts. ${ }^{27}$ In Overton Park the Supreme Court considered whether the approval of a Tennessee highway project by the Secretary of Transportation could be upheld on the basis of explanatory affidavits prepared by the agency specifically for purposes of the litigation. The Court rejected the agency's submission of affidavits and adopted instead a series of principles derived from the APA. ${ }^{28}$ The Court first held that judicial review of inforinal agency action must be based on the contemporaneous ad-

22. See, e.g., Abbott Laboratories, Inc. v. Gardner, 387 U.S. 136 (1967); see also Vining, Direct Judicial Review and the Doctrine of Ripeness in Administrative Law, 69 MICH. L. REv. 1445 (1971).

23. See Abbott Laboratories, Inc. v. Gardner, 387 U.S. 136 (1967).

24. 5 U.S.C. $\$ 702$ (1976). Federal question jurisdiction was also changed to eliminate the amount in controversy requirement in suits against the United States "or any agency thereof." 28 U.S.C. § 1331(a), as amended by Pub. L. No. 94-574, § 2; 90 Stat. 2721 (1976).

25. See, e.g., Missouri ex rel. Missouri-St. Louis Metropolitan Airport Auth. v. Coleman, 427 F. Supp. 1252 (D.D.C.), vacated and remanded without opinion sub nom. Missouri ex rel. MissouriSt. Louis Airport Auth. v. Adans, 564 F.2d 600 (D.C. Cir. 1977).

26. 401 U.S. 402 (1971).

27. 411 U.S. 138 (1973).

28. See 401 U.S. at 406, 419-20. A conservation group sued to block the expenditure of federal funds for the construction of an imterstate highway through a publie park in Memphis, Tennessee. Plaintifis alleged a violation of federal statutes prohibiting the use of federal funds to finance construction of highways through public parks if a "feasible and prudent" alternative existed. The Secretary of Transportation approved the route through the park, but he did not make any statement of findings, nor did he indicate why he believed there were no feasible and prudent alternative routes. Plaintiffs argued that the Secretary was required to make formal findings, that the Secretary had not made an independent determination with respect to the requirements of the statute, and that the Secretary's decision was incorrect on the merits because fcasible and prudent alternatives were available. Id. at 414 . The government responded that formal findings were unnecessary, $i d$. at 411 , but then produced affidavits prepared specifically for the litigation to explain and to justify the Secretary's action. See id. at 419. 
ministrative record, that is, the "whole record" compiled by the agency. ${ }^{29}$ The Court imstructed district courts to conduct a "thorough, probing, im-depth review" of the administrative record and to make a "searching and careful" analysis of the facts contained in the record to determine whether the agency action was arbitrary, capricious or otherwise imconsistent with law within the meaning of the APA.30 The Court cautioned, however, that the standard of review is ultimately very narrow and that lower courts generally must not look beyond the administrative record $\mathrm{i}$ resolving the merits of the case.

The Court nevertheless acknowledged that judicial review of agency action based on the administrative record might prove difficult $\mathrm{m}$ the absence of at least some formal findings by the agency explaining its action. Some explanation by the agency is necessary, the Court held, because "the bare record may not disclose the factors that were considered" by the agency or the agency's "construction of the evidence" before it. ${ }^{31}$ The Court therefore suggested the following principles to guide the lower courts im obtaining such an explanation:

(1) "The court may require the administrative officials who participated in the decision to give testimony explaining their action." 32

(2) If that explanation would require disclosure of "inental processes," testimony is "usually to be avoided," but not always, because "it inay be that the only way there can be effective judicial review is by examining the decisionmakers themselves." 33

(3) If the agency has already included a contemporaneous explanation of its action in the administrative record, the district court should almost never require agency officials to testify. ${ }^{34}$

(4) If it is inappropriate to require agency officials to testify, the district court may order the agency to "prepare formal findings. . . that will provide an adequate explanation" for the agency's action. "Such an explanation will, to some extent, be a 'post hoc rationalization' and thus must be viewed critically."35

(5) The court left the decision as to how best to obtain further explanation of agency action to the district court's discretion, the goal being to achieve "the inost expeditious" method. ${ }^{36}$

Within two years, the issues raised by Overton Park were again before the Supreme Court in Camp v. Pitts. ${ }^{37}$ In Camp v. Pitts, which

29. Id. at 419 .

30. Id. at $415-16$.

31. Id. at 420 .

32. $I d$.

33. $I d$.

34. Id.

35. Id.

36. Id. at $420-21$.

37. 411 U.S. 138 (1973). In Camp v. Pitts unsuccessful applicants for a new bank charter sued the Comptroller of the Currency. The Comptroller lad denied the plaintiffs' initial application in 
mvolved judicial review of an informal action of the Comptroller of the Currency, the Supreme Court specifically reaffirmed Overton Park's emphasis on the administrative record and rejected the lower court's decision to conduct review on the basis of a de novo trial. The Court noted that "the focal point for judicial review should be the administrative record already im existence, not some new record made initially in the reviewing court." 38 The Court reiterated, however, that the reviewing court could insist that the agency give some explanation for its action:

If, as the Court of Appeals held and as the Comptroller does not now contest, there was such failure to explaim administrative action as to frustrate effective judicial review, the remedy was not to hold a de novo hearing but, as contemplated by Overton Park, to obtaim from the agency, either through affidavits or testimony, such additional explanation of the reasons for the agency decision as may prove necessary. ${ }^{39}$

The Court cautioned, however, that the reviewing court should not insist on any particular kind of explanation. As long as the explanation was drafted conteinporancously with the agency's decision and the explanation was not so inadequate as to "frustrate effective judicial review," the reviewing court's only role was to decide whether the agency action would "stand or fall" on the basis of the administrative record. ${ }^{40}$

Overton Park and Camp v. Pitts form the principal foundation for judicial oversight of informal agency decisionmaking. ${ }^{41}$ The decisions establish that informal agency action is subject to judicial review, but place strict limitations on such review. In general, only the record

a brief letter that offered no explanation for the decision. Id. at 138-39. Following a supplemental field examination, the Comptroller again denied the application and set forth a limited number of supporting facts. Id. at 139. The district court granted summary judgment for the Comptroller on the basis of the administrative record and two letters of explanation, $i d$, but the court of appeals reversed on the ground that the basis of the Comptroller's decision was not statcd with sufficient clarity to permit judicial review. 463 F.2d 632 (4th Cir. 1972). The court of appeals ordered the district court to hold a trial de novo on renand because the Conptroller had so inadequatcly responded to the applicant's presentation. Id. at 634. On certiorari, the Supreme Court specifically rejected the court's call for a de novo trial and stated that "de novo review is appropriate only where there are inadequate factinding procedures in an adjudicatory proceeding, or where judicial proceedings are brought to enforce certain administrative actions." 411 U.S. at 142.

38. 411 U.S. at 142.

39. Id. at $142-43$.

40. Id.

41. Neither decision involved agency action resulting fron a procedurally well-defined decisionmaking process. It is unlikely that either agency had a centrally conpiled "adininistrative record" at the time of the Supreine Court's decision. Moreover, neither agency made any effort to provide detailed findings in support of its decision. The only formal expression of the agency decision at issue in Camp v. Pitts was the following: "[w]e have concluded that the factors in support of the establishment of a New National Bank in this area are not favorable." 411 U.S. at 138-39. 
before the agency may be consulted in considering the inerits of the agency decision. ${ }^{42}$ That highly relevant materials may exist outside the agency's files is usually not significant.

Nevertheless, the Supreme Court left open an important discretionary exception to the otherwise strict requirement that judicial review be limited to analysis of the administrative record: the district court may insist that the agency provide an adequate explanation for its action. Underlying this exception is the recognition that judicial review may be unnecessarily frustrated if the record is not complete enough to allow the district court to carry out the "searching and careful" analysis mandated by Overton Park.

Since Overton Park, further exceptions have developed, but because Overton Park forbids the introduction of evidence solely to second-guess the merits of the agency's decision, these exceptions usually have been carefully tailored. Courts have permitted additional factfinding and discovery only with respect to natters that are tangential to the inerits, relating inore to the procedures by which the decision was reached and explained.

\section{The Special Circumstances under which Discovery of AdDitional FactFinding Should be CoNSIDERED}

Private litigants who have obtained discovery or a hearing against the government generally have done so in four situations. First, where legitimate concerns are raised concerning the makeup of the administrative record, courts may permit limited discovery agamst an agency to verify the content or completeness of that record. ${ }^{43}$ There is no dispute that effective judicial review requires a "complete" record. Serious issues may arise, however, concerning what constitutes a "coinplete" record and the extent to which a private litigant should be permitted to verify completeness through discovery.

Second, courts may accept clarifying or explanatory materials to supplement the administrative record, even when that record is ostensibly complete. ${ }^{44}$ Courts nay permit supplemented factfinding when a private hitigant requests further agency explanation of its action, requests the opportunity to identify "relevant factors" not considered by the agency, or offers background materials for the court's benefit in understanding the issues. Under relatively limited circumstances,

42. 411 U.S. at 142.

43. See text accompanying notes 47-94 infra.

44. See text accompanying notes 95-183 infra. 
courts have been willing to permit some factfinding in each of these situations.

Third, courts may permit discovery or a hearing when litigants make substantial allegations of improper agency conduct. ${ }^{45}$ Courts have permitted discovery regarding allegations of agency "bad faith," improper congressional influence, or the violation of agency regulations when the allegations have substance and are not simply a pretext to engage in an inquisition of agency persoimel. Fourth, courts inay permit supplemental factfinding when there is a dispute involving the agency's interpretation of applicable regulations. The agency's prior "contemporaneous construction" of the law may be an appropriate subject for discovery or additional factfinding. 46

\section{A. Makeup of the Administrative Record.}

Defining the administrative record is the first step in inost judicial review proceedings. ${ }^{47}$ The docuinents that the agency considers to be the record are usually collected, indexed if necessary, and then certified to the court by the agency. If no objection is raised, the court will accept the record in the form in which it is certified.48 In soine cases, however, disputes arise over the proper content of the administrative record. These disputes most often concern whether the written record is "eomplete," and whether the record should include factual materials conveyed orally to agency decisionmakers but not reflected in the record. Resolution of these two issues inay require discovery or otler factinding procedures.

1. Verifying Completeness of the Record. Litigants dissatisfied with the contents of an administrative record frequently argue that the record is incomplete. ${ }^{49}$ It is often difficult, of course, for an agency to

\footnotetext{
45. See text accompanying notes $185-219$ infra.

46. See text accompanying notes 220-59 infra.

47. In most nonrulemaking cases, the "administrative record" during the course of agency decisionmaking consists of nothing inore than the files of agency employees inamtained in haphazard fashion in their various offices. See DeLong, supra note 3, at 264. In such cases, the administrative record is not defined unless an action for judicial review is brought. Once suit is brought, the agency employees involved in the inatter are contacted, their files collected, and a unitary "record" created for transmission to the court.

48. The procedures by which the administrative record is certified to the court may vary from case to case. In some cases, the agency files the record in heu of an answer to the complaimt. In other cases, the agency may produee the administrative record in response to a Rule 34 request for production of documents. Thereafter, either the agency or the private litigant inay certify the record to the court. In other cases, the agency may file the administrative record along with a motion for summary judgment.

49. It is beyond dispute that private litigants are entitled, on review of administrative action, to an administrative record that aceurately refiects the inaterials before the decisionmaker. See Madison County Bldg. and Loan Ass'n v. Federal Home Loan Bank Bd., 622 F.2d 393, 395 n.3
} 
decide what documents must be included in a "complete" administrative record. Agency files mevitably include some privileged or irrelevant information that ought not be part of the administrative record; culling agency records, therefore, necessarily requires difficult subjective judgments concerning relevancy and the scope of possible privilege claims. Although some agencies may be quite hiberal in making these judgments, ${ }^{50}$ other agencies have taken such highly selective approaches as identifymg only documents directly "relied on" by the agency decisionmaker. ${ }^{51}$ Moreover, even if an agency's decisions to include or not to include specific documents in the record are accurate, relevant documents in agency files may simply be overlooked.52

If uncertainties arise concerning whether a particular administrative record is complete, the court usually is faced with two issues: what documents must be included in the record to make it complete, and how to identify these documents on judicial review. The second issue will ordinarily involve a discovery question.

(a) Definition of the whole record. The requirement of a complete record is based on the Supreine Court's holding in Overton Park that, under section 706 of the APA, the court must review agency action based on the "whole record" compiled by the agency..$^{53}$ In response to this requirement, courts have established five guidelines for determining the scope of the administrative record. First, the record should include all documents the agency considers rather than only those on

(8th Cir. 1980); Natural Resources Defense Council, Inc. v. Train, 519 F.2d 287, 291-92 (D.C. Cir. 1975); Amoco Prod. Co. v. DOE, 29 Fed. R. Serv. 2d 402 (D. Del. 1979); Teuneco Oil Co. v. DOE, 475 F. Supp. 299, 316-19 (D. Del. 1979); Environmental Defense Fund, Inc. v. Blum, 458 F. Supp. 650, 660-61 (D.D.C. 1978); Getty Oil Co. v. DOE, [1978] ENERGY MGMT. (CCH), If 9741 (D. Del. May 4, 1978); Petrolane, Inc. v. DOE, 79 F.R.D. 115, 118-19 (C.D. Cal. 1978); Pierson v. United States, 428 F. Supp. 384, 389-90 (D. Del. 1977); A.O. Smith Corp. v. FTC, 403 F. Supp. 1000, 1008-09 (D. Del. 1975); Community Sav. \& Loan Ass'n v. Federal Home Loan Bank Bd., 68 F.R.D. 378 (E.D. Wis. 1975); cf. Murphy v. FBI, 490 F. Supp. 1134 (D.D.C. 1980) (in FOIA cases, discovery appropriate only after government answer creates a factual dispute).

50. See Pederseu, Formal Records and Informal Rulemaking, 85 YALE L. J. 38, 66-70 (1975).

51. See Natural Resources Defense Council, Inc. v. Train, 519 F.2d 287, 292 (D.C. Cir. 1975); Environmeutal Defense Fund, Inc. v. Blunt, 458 F. Supp. 650, 661 (D.D.C. 1978) (involving "the anomalous situation . . . that highly relevant submissions in the agency's files are not considered by EPA to be part of the record," apparently because the agency was attempting to skew the record for review in its favor); A.O. Smith Corp. v. FTC, 403 F. Supp. 1000, 1008 (D. Del. 1975).

52. During agency decisionmaking process, the record can take many different forms. Some agencies, particularly in the case of rulemaking, may impose relatively strict procedures to ensure the creation of a fornal record during the course of a decisionmaking process. See Pedersen, supra note 50, at 66-70. The record at other agencies may consist of nothing more than "teus of thousands of papers strewn aunong a dozen offices." DeLong, supra note 3, at 264. In the latter case, there is obviously greater potential for error in the process of identifying an administrative record appropriate for judicial review.

53. 401 U.S. at 419. 
which the agency relies. ${ }^{54}$ Second, if the agency decisionmaker's decision is based on the work and recommendations of subordinates, ${ }^{55}$ the record should include all documents considered by the agency employees whose input reached the decisionmaker. ${ }^{56}$ Documents in agency files that merely relate to the subject matter of the agency decision need not be mcluded in the record unless they were considered or relied on by agency personnel involved in the decision. ${ }^{57}$ Third, raw data that is bona fide confidential business information ordinarily need not be included in the administrative record. ${ }^{58}$ Fourth, deliberative intraagency memoranda and staff reports should ordinarily be excluded from the administrative record. 59 When the agency has made no findings to explain its decision or when its findings are incomplete, how-

54. See Amoco Prod. Co. v. DOE, 29 Fed. R. Serv. 2 d 402 (D. Del. 1979); Pierson v. United States, 428 F. Supp. 384, 392 (D. Del. 1977). These decisions express the realistic concern that if an agency were only required to produce the documents on which it rehed, the agency might produce only those documents that support its position.

55. In cases in which the agency decisionmaker functions in a manner analogous to an administrative law judge, the record consists only of documents that the decisionmaker considers. See Shell Oil Co. v. DOE, 477 F. Supp. 413 (D. Del 1979), affd, 631 F.2d 231 (3d Cir. 1980), cerr. denied, 450 U.S. 1024 (1981); Getty Oil Co. v. DOE, [1978] ENERGY MGMT. (CCH) II 9741 (D. Del. May 4, 1978); see also Quincy Oil, Inc. v. FEA, 468 F. Supp. 383 (D. Mass. 1979); Community Sav. \& Loan Ass'n v. Federal Home Loan Bank Bd., 68 F.R.D. 378 (E.D. Wis. 1975).

56. See Tenneco Oil Co. v. DOE, 475 F. Supp. 299 (D. Del. 1979); Pierson v. United States, 428 F. Supp. 384 (D. Del. 1977). But see Dopico v. Goldschmidt, 518 F. Supp. 1161 (S.D.N.Y. 1981). In Dopico, the court denied discovery to flesh out facts suggested in a subordinate's memorandum: "it is the final decision, and the facts and considerations directly relied on by the ultimate decisionmaker in making that decision, that are the subject of review in district court." 518 F. Supp. at 1181.

57. See Amoco Prod. Co. v. DOE, 29 Fed. R. Serv. 2d 402 (D. Del. 1979). But see Environmental Defense Fund, Inc. v. Blum, 458 F. Supp. 650 (D.D.C. 1978). Environmental Defense Fund suggests that documents "which had existed in EPA's file" as of the date of the final decision should be included in the record. Id. at 655 . Most courts probably would adopt the presumption that nonprivileged documents contained in agency files concerning the specific matter in question are part of the administrative record absent a strong showing that the documents are irrelevant to the subject matter of the agency's decision. If the plaintiff challenges not only the merits of an agency decision, but also the procedures by which the decision was reacled, the administrative record may be broader and may include documents that reveal agency procedures. See Bethlehem Steel Corp. v. EPA, 638 F.2d 994 (7th Cir. 1980). This inquiry, however, may still be subject to privilege claims and the need to satisfy the court that the procedural attack has some merit. See text accompanying notes 185-219 infra.

58. See Atchison, T. \& S. F. Ry. v. Alexander, 480 F. Supp. 980, 995 (D.D.C. 1979). In most cases, the litigant's need for a third party's confidential business information in the possession of the government is outweighed by the need to keep the information confidential. However, in some cases it may be necessary either to release a portion of the confidential information or to submit portions of the record under a protective order prohibiting its use for any purpose other than the litigation. Protective orders have been used effectively in some cases.

59. See Madison County Bldg. \& Loan Ass'n v. Federal Home Loan Bank Bd., 622 F.2d 393, 395 n.3 (8th Cir. 1980); National Nutritional Foods Ass'n v. Mathews, 557 F.2d 325, 331 (2d Cir. 1977); cf. A.O. Smith Corp. v. FTC, 403 F. Supp. 1000 (D. Del. 1975) (an agency does not have the right to designate whatever it considers to be the administrative record and to refuse to submit, 
ever, the court may require inclusion of deliberative memoranda in the administrative record to provide a contemporaneous explanation for the agency's decision. ${ }^{60}$ Materials that provide factual support for materials in the record need not be part of the record unless they were reviewed or considered by the agency personnel involved in the decision. ${ }^{61}$

The enunciation of these principles is only the first step, lowever, in verifying the completeness of an administrative record. In cases in which serious questions arise concerning the completeness of the administrative record, courts must address a second issue and consider the use of discovery procedures to verify completeness.

(b) Procedures for verifying the completeness of the record.

The grant of discovery to verify coinpleteness of an administrative record is far from automatic. Generally, courts require a showing that the plaintiff's concern about coinpleteness has some reasonable basis. ${ }^{62}$ Private litigants are probably in the best position to make out the required showing of incompleteness if they have filed appropriate requests for production of documents under Rule 34 of the Federal Rules of Civil Procedure. A request for "all documents constituting the administrative record including, without limitation, eacli of the following categories of documents" will ordinarily begin the process. The government agency, im inaking its response, ordinarily is required eitler to produce the record in conforinance with plaintiff's request or to identify the respects in which the agency believes the request is overly broad. ${ }^{63}$ This process sharpens the issues that the court is then expected to decide.

either to the court or to the agency's adversaries, other materials used by the agency in formulating its rule).

60. See County of Suffolk v. Secretary of Interior, 562 F.2d 1368, 1384 (2d Cir. 1977), cert. denied, 434 U.S. 1064 (1978); see also North Slope Borough v. Andrus, 642 F.2d 589 (D.C. Cir. 1980).

61. See Tenneco Oil Co. v. DOE, 475 F. Supp. 299 (D. Del. 1979); Shell Oil Co. v. DOE, No. 79-134 (D. Del. May 31, 1979).

62. See National Resources Defense Council, Inc. v. Train, 519 F.2d 287, 291-92 (D.C. Cir. 1975); Tenneco Oil Co. v. DOE, 475 F. Supp. 299, 317-18 (D. Del. 1979); Petrolane Inc. v. DOE, 79 F.R.D. 115, 118-19 (C.D.Ca. 1978); Getty Oil Co. v. DOE, [1978] ENERGY MGMT. (CCH) I 9741 (D. Del. 1978). The required showing may be made in a variety of ways. Typically the plaintiff identifies gaps in the record in some general manner. In an unusual case, he may be able to note specific documents excluded froin the record.

63. An agency may or may not voluntarily represent that the administrative record it produces is responsive in all respects to the private litigant's request for production of docunents. If an agency does not so certify, the private litigant will ordinarily seek a meeting with government counsel. At such a meeting, counsel for the parties can either review the documents in dispute or discuss the necessity for producing specific categories of requested documents. If the meeting between counsel does not entirely resolve the differences, plaintiff usually has made out a basis (if his definition of the administrative record is correct) either for a motion to compel further production or for discovery in an appropriate case. 
A second method for focusing the claim of an incomplete record involves the Freedom of Information Act (FOIA). Many of the documents that constitute an administrative record are available to anyone at any time under the FOIA. Though subject to certain statutory exemptions, ${ }^{64}$ a FOIA request frequently provides a useful check on the completeness of the administrative record. ${ }^{65}$

If a request for documents under either Rule 34 or the FOIA results in the agency's identification of the documents being withheld the reviewing court may, on motion, resolve the propriety of the agency's decision to withhold the documents. Interrogation of agency officials is ordinarily not required to resolve such a notion because the documents in dispute are known and the only issue is whether the documents should be included in the record. ${ }^{66}$

Inevitably, cases arise in which the private litigant asserts, without knowing the precise documents being withheld, that the record is incomplete. The private litigant, for exainple, may not have filed a request for production of documents, ${ }^{67}$ or he may assert that the agency

64. There are nine statutory exemptions. See 5 U.S.C. $\$ 552(b)(1)-(9)$ (1976). The principal exemptions protect trade secrets (exemption 4), predecisional deliberations and opinions (exemption 5), and investigative files (exemption 7).

65. See Bethlehem Steel Corp. v. EPA, 638 F.2d 994, 1000 (7th Cir. 1980). FOIA requcsts generally may be phrased in the same forn that a litigant's subsequent Rule 34 request would take. If the request seeks documents that are exempt under the Act, those documents will be withheld. It is often the FOIA officer at the agency, however, who makes the decisions on withholding documents requested under that Act, rather than the decisionmakers themselves. The FOIA officer may be more liberal in producing agency records.

66. Once the identity of the documents in dispute is known, the form of the motion for resolution of whether the documents should be included in the record may vary. If a Rule 34 request for production of documents has been filed, the best vehicle is a Rule 37 motion to compel production predicated on the agency's incomplete response to the Rule 34 request. The Rule 34 request will have set forth by specific category the types of documents that the plaintiff believes should be included in the record. If counsel for the parties have discussed the matter - which the court should ordmarily insist on prior to ruling on any formal motions - the parties will be able to present to the court a narrow dispute concerning either specific documents that can be shown to the court or specific categories of documents that can be described with some particularity by reference to the Rule 34 request. Under these circunstances, the issues in dispute usually turn on whether particular categories of documents are necessarily part of an administrative record, i.e., documents considered by the agency, or whether they fall within the various categorics of documents that should not be in the record (for example, privileged documents).

67. This may oceur either because the private hitigant for some reason chooses not to file such a request, or because, under the applicable statute, the case is brought in the first instance in circuit court rather than in district court. See Natural Resources Defense Council, Inc. v. Train, 519 F.2d 287 (D.C. Cir. 1975). In these cases, the competing contentions of the parties can be initially focused through meetings of counsel. If the documents in dispute can be identified in this way, the parties are in a position to set forth their conflicting positions through written submissions to the court, either by affidavits or otherwise. A "motion to compel production of a complete record" or some similarly entitled motion would suffice. That judicial review begins in the court 
either failed to search all of its files or made a search that was too cursory. In such cases, it may be that neither party knows the exact identity of additional documents that might be needed to complete the record.

Under these circumstances, the private litigant may seek to interrogate agency personnel through depositions, and the decision whether to grant such discovery generally lies within the discretion of the court. The court, at least initially, may decide not to reach the merits of the discovery request and instead first permit affidavits from the parties, ${ }^{68}$ require informal meetings of counsel, ${ }^{69}$ or adopt other less intrusive procedures. Indeed, when depositions are requested, ${ }^{70}$ courts ordinarily insist on some statement of the competing contentions of the parties, through affidavits or otherwise, before authorizing the discovery. ${ }^{71}$ For example, the parties may be expected to provide descriptions of the manner in which the administrative record was compiled and collected,72 and to state their positions concerning the extent to which gaps exist in the record that can not be satisfactorily explained by the agency. ${ }^{73}$ The showings required vary, of course, with the facts of the particular case. ${ }^{74}$

of appeals should not preclude sufficient procedures to guarantee the adequacy of the record. See National Nutritional Foods Ass'n v. FDA, 491 F.2d 1141, 1144, cert. denied, 419 U.S. 874 (1974).

68. See Quincy Oil, Inc. v. FEA, 468 F. Supp. 383 (D. Mass. 1979), affd, 620 F.2d 890 (Temp. Emer. Ct. App. 1980); cf. Murphy v. FBI, 490 F. Supp. 1134 (D.D.C. 1980) (necessity of discovery cannot be determined before the opposing party files answer).

69. Cf. Amoco Prod. Co. v. DOE, 29 Fed. R. Serv. 2d 402, 406 (D. Del. 1979) (court orders meeting of counsel to narrow scope of discovery).

70. The discovery motion may take the form of either a request by the plaintiff for authorization to initiate discovery or, if the plaintiff intiated discovery without court approval, as he usually can do under the Federal Rules, a motion for a protective order by the federal agency.

71. See generally Natural Resources Defense Council, Inc. v. Train, 519 F.2d 287 (D.C. Cir. 1975); Tenneco Oil Co. v. DOE, 475 F. Supp. 299 (D. Del. 1979); Getty Oil Co. v. DOE, [1978] ENERGY MGMT. (CCH) II 9741 (D. Del. May 4, 1978).

72. See note 52 supra.

73. When complete production of documents is sought in nongovernmental hitigation litigants enjoy considerable flexibility in ensuring the complete production of all relevant documents. They can fashion a variety of Rule 34 requests for documents, liave subpoenas issued, and take depositions regarding the existence and location of documents.

Nevertheless, almost all civil cases of any size involve soine stumbling blocks in obtaining all relevant documents because when the files of a large corporation or other organization are being searched production of inaterials froin those files may depend on the diligence of many people, eacl of whoin mnst apply some consistent standard of relevance if the search is to be effective. Thus, documents are commouly missed in the first searcli of a coinpany's files. In addition, inany hitigators are prone to construe narrowly an adversary's request for documents when such a construction nright avoid production of damaging materials.

74. In granting deposition discovery courts may be influenced, for exainple, by a showing that the agency was highly selective in identifying the record. See Environmental Defense Fund, Inc. v. Blum, 458 F. Supp. 650, 661 (D.D.C. 1978); A.O. Sunith Corp. v. FTC, 403 F. Supp. 1000, 1008-09 (D. Del. 1975). 
In determining the required showing, courts would do well to follow the analogous cases that have arisen under the FOIA. FOIA cases are relevant not only because the issue - whether all of the requested documents have been produced - is comparable but also because most categories of documents in the typical administrative record are subject to production and inay indeed have been requested under the FOIA independent of their production as part of an administrative record in litigation. There is good reason, therefore, to use the saine rules for determining the coinpleteness of an agency's search for records whether that search is pursuant to judicial review of agency action or pursuant to a FOIA request.

The Court of Appeals for the District of Columbia Circuit has recently decided a series of cases concerning whether the governinent's search for records requested under the FOIA was sufficiently thorough and complete. ${ }^{75}$ These decisions establish reasonably detailed discovery standards concerning the coinpleteness of the agency's record. Under these cases, the agency has the burden of demonstrating the completeness of its search. ${ }^{76}$ Ordinarily, the agency will seek to satisfy this burden through affidavits. ${ }^{77}$ If the agency's affidavits are "relatively detailed," "nonconclusory," and submitted in good faith, the court has discretion to forego discovery and award summary judgment on the basis of the affidavits. ${ }^{78}$ If the private litigant submits facts that, when viewed in the hight nost favorable to that litigant, rebut the agency's showing of a thorough search, summary judgment is inappropriate. Discovery and, if necessary, a hearing may be permitted. ${ }^{79}$

75. See Weisberg v. United States Dep't of Justice, 627 F.2d 365 (D.C. Cir. 1980); Goland v. CIA, 607 F.2d 339 (D.C. Cir. 1978), cert. denicd, 445 U.S. 927 (1980); Murphy v. FB1, 490 F. Supp. 1134 (D.D.C. 1980). Sec also Weisburg v. Department of Justice, 543 F.2d 308 (D.C. Cir. 1976); Schaffer v. Kissinger, 505 F.2d 389 (D.C. Cir. 1974); Association of Nat'1 Advertisers v. FTC, 1976-1 Trade Cas. \ 60835 (D.D.C. 1976); Exxon Corp. v. FTC, 384 F. Supp. 755 (D.D.C. 1974), remanded without opinion, 527 F.2d 1386 (1976).

76. See Weisberg v. United States Dep't of Justice, 627 F.2d 365, 368 (D.C. Cir. 1980); Goland v. CIA, 607 F.2d 339, 352 (D.C. Cir. 1978), cert. denied, 445 U.S. 927 (1980). As stated in Weisberg, "the defending agency nust prove that each document that falls within the class requested either has been produced, is unidentifiable or is wholly exempt from the Act's mspection requirements." " 627 F.2d at 368 (quoting National Cable Television Ass'n v. FCC, 479 F.2d 183, 186 (D.C. Cir. 1973)).

77. Sce Weisberg, 627 F.2d at 365; cf. Murphy v. FBI, 490 F. Supp. 1134, 1137 (D.D.C. 1980)(discovery premature before government filed affidavits).

78. Goland v. CIA, 607 F.2d 339, 352 (D.C. Cir. 1978), cert. denied, 445 U.S. 927 (1980)(quoting Vaughn v. Rosen, 484 F.2d 820, 826 (D.C. Cir. 1973), cert denied, 415 U.S. 977 (1974)); Nolen v. Rumsfeld, 535 F.2d 890, 891-92 (5th Cir. 1976), cert. denied, 424 U.S. 1104 (1977).

79. See Weisberg v. United States Dep't of Justice, 627 F.2d 365, $368-69$ (D.C. Cir. 1980). This standard is derived fron the normal requirements under Rule 56 governmg summary judg. ment. In ruling on such motions, factual matters are to be viewed in the light most favorable to 
These principles can be readily applied to administrative record cases. ${ }^{80}$ To resolve legitimate issues concerning completeness of the record, courts should imsist on relatively detailed and nonconclusory affidavits from the agency officials describing the file system, identifying the files searched and the method of search, and identifying the personnel participating in the search. The court should give the private litigant, even when detailed agency affidavits are filed, the opportunity to produce countervailing evidence, and it should give the private litigant the benefit of the doubt when the court decides whether to authorize discovery concerning facts in genuine dispute. ${ }^{81}$

This last principle might be questioned by some courts. The summary judgment standards that are applied in FOIA cases require issues of fact to be viewed most favorably to the party opposing summary judgment. ${ }^{82}$ These standards are not applicable when the issue before the court simply imvolves completeness of an administrative record. In addition, various presumptions favor the agencies im administrative record cases. It seeins mappropriate, however, to resolve factual disputes concerning the completeness of the record in the agency's favor as a matter of presumption for two reasons. First, the general discovery rules favor broad pretrial discovery of facts in order to focus more sharply the issues before the court. ${ }^{83}$ The issue of completeness of the record is collateral to the merits, and discovery to develop facts relating to that issue will not burden the court's ability to deal with the inerits, and it presumably may enhance it. Second, because the same administrative record documents may be subject to production either during the litigation or im response to imdependent FOIA requests, it makes sense to have comparable rules for resolving the issue of completeness regardless of the form of the request.

In summary, there are good reasons not to unleasli discovery absent a legitimate dispute over the completeness of the administrative record. Upon a legitimate showing of possible incompleteness, lowever, the court should encourage and closely supervise a full considera-

the party opposing the motion. Adickes v. S.H. Kress \& Co., 398 U.S. 144, 157 (1970). In administrative record cases, summary judgment is frequently appropriate. See Fishbock v. United States, 519 F. Supp. 190, 194 n.1 (D.N.M. 1981).

80. Many courts have followed procedures roughly similar to those followed in FOIA cases when determining the completeness of an administrative record. See, e.g., Natural Resources Defense Council, Inc. v. Train, 519 F.2d 287, $291-92$ (D.C. Cir. 1975); Tenneco Oil Co. v. DOE, 475 F. Supp. 299,317 (D. Del. 1979); Quincy Oil, Inc. v. FEA, 468 F. Supp. 383 (D. Mass. 1979), aff'd, 620 F.2d 890 (Temp. Einer. Ct. App. 1980); Getty Oil Co. v. DOE, [1978] EnERgY . MGMT.(CCH) \ 9741 (D. Del. 1978).

81. See Weisberg v. United States Dep't of Justice, 627 F.2d 365, 370-71 (D.C. Cir. 1980).

82. See Adickes v. S.H. Kress \& Co., 398 U.S. 144, 160 (1970).

83. See C. Wright, Handbook on the Law of Federal Courts $\$ 81$ (3d ed. 1976). 
tion of the issues through requests for production of documents under Rule 34, conferences between counsel, motions to compel under Rule 37, and limited depositions.

2. Non-Recorded Oral Communications. An issue closely related to whether the administrative record contams all relevant material is whether the record adequately reflects oral communications between government decisionmakers and private parties. Ordmarily, such oral contacts do not occur during rulemaking because case law prohibits ex parte contacts in such proceedings. ${ }^{84}$ In informal nonrulemaking actions, however, there are often no such restrictions governing the agency decisionmaking process. Indeed, agencies not constraimed by the ex parte prohibitions governimg rulemaking and formal adjudication frequently obtain much of the information on which they base their decisions from outside sources, usually on an ex parte and frequently oral basis. Not all of these oral discussions are reduced to writing, and the agency's procedures may not address this issue.

If important oral communications with agency decisionmakers or their direct subordinates are not reduced to writing, there may be important gaps im the record concerning the factors that actually influenced the decisionmaker: Few cases have considered this problem squarely. ${ }^{85}$ In Shell Oil Co. $v . D O E,{ }^{86}$ the court declined to reach the issue of whether records of oral commumications between agencies should have been kept and mcluded in the administrative record, but granted discovery for the purpose of identifying and examining the communications. The court implied that if discovery demonstrated that the oral communications had a significant impact on the agency's decisionmaking process, the agency might be required to augment the administrative record. ${ }^{87}$

In Lukens Steel Co. v. Kreps ${ }^{88}$ the court reached a different result: it denied discovery of the circunistances surrounding the agency's re-

84. Agencies are required to reduce ex parte oral contacts to writing and make them available for public comment. See National Small Shipments Traffic Conference, lnc. v. 1CC, 590 F.2d 345 (D.C. Cir. 1978); United States Lines, Inc. v. Federal Maritime Comm'n, 584 F.2d 519 (D.C. Cir. 1978); Houne Box Office, Inc. v. FCC, 567 F.2d 9, $55-57$ (D.C. Cir.), cert. denied, 434 U.S. 829 (1977).

85. See, e.g., Lukens Steel Co. v. Kreps, 477 F. Supp. 444 (E.D. Pa. 1979), rev'd on other grounds sub nom. 629 F.2d 881 (3d Cir. 1980); Shell Oil Co. v. DOE, No. 79-134 (D. Del. May 31, 1979).

86. No. 79-134 (D. Del. May 31, 1979). The plaintiffs alleged that the Department of Energy had developed a financial reporting systen based in part on oral discussions with representatives of the FTC, the Department of Justice, and the EPA.

87. Id., slip op. at 6.

88. 477 F. Supp. 444 (E.D. Pa. 1979), rev'd on other grounds sub nom. Lukens Steel Co. v. Klutznick, 629 F.2d 881 (3d Cir. 1980). 
ceipt of ex parte communications from third parties. The plaintiffs asserted that the agency had been orally apprised of important information that was not recited in the record but that bore directly on the merits of the case. The court held that the Overton Park Court did not contemplate discovery under such circuinstances and noted that the complete administrative record was before the court. ${ }^{89}$

In light of Overton Park, the rationale of Shell Oil rather than that of Lukens Steel seems correct. In Overton Park the Supreine Court acknowledged the need for supplementation in those cases in which "the bare record may not disclose the factors that were considered" by the agency decisionmaker. ${ }^{90}$ If important information communicated orally is not reflected in the administrative record, it seems essential to require supplementation of the record through some appropriate procedure.

Three possible factfinding procedures may be useful in these cases: the agency could submit affidavits or other written summaries of the oral communication; depositions could be taken of the agency decisionmakers; or depositions could be taken from the third parties who communicated the information to the agency. The procedure chosen should vary with different fact patterns. In general, permitting a written supplementation by the agency imposes the least burden on the agency and is least likely to present problems of agency privilege $e^{91}$ or runaway discovery. On the other hand, written submissions by the agency 'will, to some extent, be a 'post hoc rationalization' and thus must be viewed critically." 92 If this danger is significant, depositions may be more appropriate. Depositions of third parties, though burdensome on nonparty witnesses, may have the advantage of avoiding any questions of agency privilege.

As with cases challenging the completeness of the administrative record, however, courts must be careful to control the discovery process and not to permit wide ranging discovery absent some specific showing that important oral communications are not reflected in the record. In many cases, the essential facts communicated in an oral discussion are reflected in other docunients already a part of the record. In such cases, supplementation of the record may duplicate material in the record and

89. Lukens Steel Co. v. Kreps, 477 F. Supp. 444 (E.D. Pa. 1979), rev'd on other grounds sub nom, Lukens Steel Co. v. Klutznick, 629 F.2d 881 (3d Cir. 1980). Lukens Steel involved the grant of financial assistance by the Department of Commerce to a competitor of Lukens. The agency received, ex parte, voluminous material from both the competing company and from Lukens to determine whether the competing company qualified for assistance.

90. 401 U.S. at 420.

91. See text accompanying notes 260-302 infra.

92. Overton Park, 401 U.S. 402, 420 (1971). 
may therefore be unnecessary. Moreover, even when orally communicated information is not in the record, courts should require some showing that the information is relevant to the agency decision before orderimg supplementation. As in the cases governing ex parte communications in rulemaking proceedings, ${ }^{93}$ courts should be convinced that the information conveyed orally is important. When a court is uncertaim whether the material was important to the agency, it may order the agency to summarize the oral commumication to better evaluate whether discovery should be permitted. ${ }^{94}$

\section{B. Supplementary Materials That Explain or Clarify the Record.}

Even when an administrative record is coinplete, the court may need supplementary materials to aid it in understanding the record. If the court is persuaded that such material is necessary and is not being submitted solely to challenge the merits of the agency's decision, ${ }^{95}$ the court often will permit supplementation of the rccord.

1. Types of Permissible Supplementary Materials. Judicial justifications for permitting supplementary materials of a clarifying or explanatory nature nearly always begin with the Supreme Court's decisions in Overton Park ${ }^{96}$ and Camp v. Pitts. ${ }^{97}$ In broad language that has had remarkable staying power over the years, the Court in Overton Park stated that if the administrative record does not disclose

93. Courts do not require public notice and comment with respect to ex parte communications absent some slowing that the information communicated to the agency is important. See Raz Inland Navigation Co. v. ICC, 625 F.2d 258 (9th Cir. 1980). In rulentaking cases, the ex parte line of cases, beginning with Home Box Office, Inc. v. FCC, 567 F.2d 9, $55-57$ (D.C. Cir.), cert. denied, 434 U.S. 829 (1977), requires that important orally communicated information be reduced to writing and made available to the public for notice and comment. Although notice and comment procedures are not required when an agency decisionmaking process contemplates ex parte contacts, requiring reduction of important contacts to writing in suclr cases would facilitate the judicial review required by Overton Park.

94. Cf. Smithkline Corp. v. FDA, 587 F.2d 1107 (D.C. Cir. 1978). In Smithkline the FDA refused to permit the plaintiff to submit relevant evidence im support of plaintiffs petition for a new drug application. The court held that this action effectively prevented creation of an administrative record and remanded for further proceedings. Arguably, if a court has power to remand because the agency las not acquired sufficient information, the court should be cmpowered to require an agency that has received information orally to reduce it to writing for purposes of judicial review.

95. If supplementation of the record is sought simply as a way of attacking the judgments made by the agency, the courts consistently and properly refuse to allow the supplemeutation. See Quincy Oil, Inc. v. FEA, 468 F. Supp. 383, 387-88 (D. Mass. 1979), affd, 620 F.2d 890 (Temp. Emer. Ct. App. 1980) (refusing discovery even for the purpose of revealing "blatant errors" made by the agency); Philadelphia Council of Neighborhood Orgs. v. Coleman, 437 F. Supp. 1341 (E.D. Pa. 1977).

96. 401 U.S. 402 (1971).

97. 411 U.S. 138 (1973). 
"the factors that were considered or the Secretary's construction of the evidence," 98 the court may require some additional explanation of the agency action. In Camp v. Pitts the Court refined this doctrine by requiring a showing that "there was such failure to explain administrative action as to frustrate effective judicial review."99 On such a showing, the remedy is "to obtain from the agency, either through affidavits or testimony, such additional explanation of the reasons for the agency decision as may prove necessary." 100

In the initial period following Overton Park and Camp v. Pitts, many courts read this language narrowly. ${ }^{101}$ They noted that the Supreme Court was not encouraging lower courts to eunbark on their own independent factfinding missions. ${ }^{102}$ Indeed, in Camp v. Pitts, the lower court had approved some additional factfinding procedures, and the Supreme Court reversed specifically on the ground that the agency's "curt" explanation - that "the factors in support of the estabhishment of a new National Bank in this area are not favorable" - may not have been so inadequate as to "frustrate effective judicial review" or to justify additional factfinding. ${ }^{103}$

Nevertheless, in reccnt years, there has been a trend toward perinitting supplementation of the administrative record, particularly in complex cases. Analytically, the cases fall into three groups. First, the court may require further agency explanation when the agency's contemporaneous explanation is so inadequate as to frustrate effective judicial review. ${ }^{104}$ Second, if a statute specifically requires an agency to examine a series of "relevant factors," suppleinentation may be permitted to identify those factors or to determine whether they were in fact

98. 401 U.S. at 420.

99. 411 U.S. at $142-43$.

100. Id.

101. See, e.g., Philadelphia Council of Neighborhood Orgs. v. Coleman, 437 F. Supp. 1341 (E.D. Pa. 1977); Missouri ex rel. Missouri-St. Louis Metropolitan Airport Auth. v. Coleman, 427 F. Supp. 1252 (D.D.C.), vacated and remanded without opinion sub nom. Missouri ex rel. MissouriSt. Louis Metropolitan Airport Auth. v. Adams, 564 F.2d 600 (D.C. Cir. 1977).

102. The courts rehed on cautionary language in Overton Park. Although noting the "failure of the Secretary to make formal findings and state his reason" for the agency action, and acknowledging that "review of the Secretary's action is hampered by his failure to make sucl findings," the Overton Park court held that "the absence of formal findings does not necessarily require that the case be remanded to the Secretary." 401 U.S. at 417. Similarly, in Camp v. Pitts, the Court warned that "the focal point for judicial review should be the administrative record already in existence, not some new record made initially in the reviewing court." 411 U.S. at 142.

103. 411 U.S. at 138-39, 142-43. The Court remanded for a determination of whether the agency explanation was inadequate in light of the Court's ruling. Id. at 143.

104. See text accompanying notes 108-29 infra. 
considered in a particular action. ${ }^{105}$ Third, the court may simply feel unable to deal with the complexity of the subject matter of a particular agency action without background materials. ${ }^{106}$ In each of these cases, the principal purpose of supplementation is to determine what the agency decided and how the decision was reached. Supplementation strictly to attack or to support the correctness of the agency's decision is not allowed; the merits of that decision must be judged on the administrative record alone. ${ }^{107}$ This line is often difficult to draw, but is nevertheless of critical importance.

(a) Further agency explanation. The case law ${ }^{108}$ is inconsistent ${ }^{109}$

105. See text accompanying notes $130-46$ infra. The Supreme Court in Overton Park emphasized that a court reviewing agency action "must consider whether the decision was based on a consideration of the relevant factors." 401 U.S. at 416.

106. See text accompanying notes $147-50$ infra.

107. Camp v. Pitts, 411 U.S. 138, 143 (1973).

108. See generally Sierra Club v. Costle, 657 F.2d 298 (D.C. Cir. 1981); Bethlehem Steel Corp. v. EPA, 638 F.2d 994 (7th Cir. 1980); Madison County Bldg. \& Loan Ass'n. v. Federal Home Loan Bank Bd., 622 F.2d 393 (8th Cir. 1980); ASARCO, Inc. v. EPA, 616 F.2d 1153 (9th Cir. 1980); Columbia Gas Transmission Corp. v. Federal Energy Regulatory Comm'n, 628 F.2d 578, 593 (D.C. Cir. 1979); City Federal Sav. \& Loan Ass'n v. Federal Home Loan Bank Bd., 600 F.2d 681 (7th Cir. 1979); Smithkline Corp. v. FDA, 587 F.2d 1107, 1118 (D.C. Cir. 1978); National Nutritional Foods Ass'n v. Mathews, 557 F.2d 325 (2d Cir. 1977); City of Des Plaines v. Metropolitan Sanitary Dist., 552 F.2d 736, 737-38 (7th Cir. 1977); United States v. Nova Scotia Food Prods. Corp., 568 F.2d 240 (2d Cir. 1977); Doriaswamy v. Secretary of Labor, 555 F.2d 832, 839-42 (D.C. Cir. 1976); Independent Meatpackers Ass'n v. Butz, 526 F.2d 228, 238-40 (8th Cir. 1975), cert. denied, 424 U.S. 966 (1976); Natural Resources Defense Council, Inc. v. Traim, 519 F.2d 287 (D.C. Cir. 1975); National Nutritional Foods Ass'n v. Weimberger, 512 F.2d 688, 701-02 (2d Cir. 1975); KFC Nat'1 Manageınent Corp. v. NLRB, 497 F.2d 298 (2d Cir. 1974), cert. denied, 423 U.S. 1087 (1976); National Nutritional Foods Ass'n v. FDA, 491 F.2d 1141 (2d Cir.), cert. denied, 419 U.S. 874 (1974); Dry Color Mfrs. Ass'n v. Department of Labor, 486 F.2d 98 (3d Cir. 1973); Bank of Commerce v. City Nat'l Bank of Laredo, 484 F.2d 284 (5th Cir. 1973), cert. denied, 416 U.S. 905 (1974); Bradley v. Weinberger, 483 F.2d 410 (1st Cir. 1973); Schicke v. Romney, 474 F.2d 309 (2d Cir. 1973); Kemecott Copper Corp. v. EPA, 462 F.2d 846 (D.C. Cir. 1972); St. Joseph's Hosp. Health Center v. Blue Cross, 489 F. Supp. 1052 (N.D.N.Y.), affd mem., 614 F.2d 1290 (2d Cir. 1979); Quincy Oil, Inc. v. FEA, 468 F. Supp. 383 (D. Mass. 1979), affd, 620 F.2d 690 (Temp. Emer. Ct. App. 1980); Gulf Oil Corp. v. Schlesinger, 465 F. Supp. 913 (E.D. Pa. 1979); NAACP v. Wilmington Medical Center, Inc., 453 F. Supp. 280 (D. Del. 1978); Philadelphia Council of Neighborhood Orgs. v. Coleınan, 437 F.Supp. 1341 (E.D. Pa. 1977); Missouri ex rel. Missouri-St. Louis Metropolitan Airport Auth. v. Coleman, 427 F. Supp. 1252 (D.D.C.), vacated and remanded without opinion sub nom, Missouri ex rel Missouri-St. Louis Metropolitan Airport Auth. v. Adams, 564 F.2d 600 (D.C. Cir. 1977); National Nutritional Foods Ass'n v. Mathews, 408 F. Supp. 303 (W.D. Tex. 1976); A.O. Smith Corp. v. FTC, 403 F. Supp. 1000 (D. Del. 1975); Community Sav. \& Loan Ass'n v. Federal Hoine Loan Bank Bd., 68 F.R.D. 378 (E.D. Wis. 1975).

109. The Courts of Appeals for the Second, Third, Seventh, Nith, and District of Colunnbia Circuits have each stated authoritatively that additional agency explanation should be required in appropriate cases. See National Nutritional Food Ass'n v. Weinberger, 512 F.2d 688, 701 (2d Cir.), cert. denied, 423 U.S. 827 (1975); National Nutritional Foods Ass'n. v. Mathews, 418 F. Supp. 394, 396 (S.D.N.Y. 1976), rev'd on other grounds, 557 F.2d 325, 331 (2d Cir. 1977); Dry Color Mfrs. Ass'n v. Department of Labor, 486 F.2d 98, 107 (3d Cir. 1973); Bethlehem Steel Corp. v. EPA, 638 F.2d 994, 1000 (7th Cir. 1980); City Fed. Sav. \& Loan Ass'n v. Federal Home Loan 
on the issues of whether and to what extent additional agency explanation should be required. This uncertainty can be illustrated by coinparing two recent cases that reached opposite holdings on very similar facts. In two cases with facts similar to Camp v. Pitts, City Federal Savings and Loan Association v. Federal Home Loan Bank Board ${ }^{110}$ and Madison County Building and Loan Association v. Federal Home Loan Bank Board, "11 plaintiffs challenged decisions by the Federal Hoine Loan Bank Board granting operating authority to a competing bank. The Board in each case had provided a very terse explanation of its actions. The Court of Appeals for the Seventh Circuit in City Federal granted the plaintiff's request for additional explanation and reinanded the case to the agency. ${ }^{112}$ In Madison County, the Court of Appeals for the Eighth Circuit refused a similar request and affirmed the district court's grant of summary judginent without requiring any additional information froin the agency. ${ }^{113}$

Bank Bd., 600 F.2d 681, $692-93$ (7th Cir. 1979); ASARCO, Inc. v. EPA, 616 F.2d 1153 (9th Cir. 1980); Columbia Gas Transmission Corp. v. Federal Energy Regulatory Comm'n, 628 F.2d 578, 593 (D.C. Cir. 1979); ASG Indus. v. Consumer Prod. Safety Comm'n, 593 F.2d 1323, 1329-30 (D.C. Cir.) ("reasoned decisionmaking" required), cert. denied, 444 U.S. 864 (1979); cf. National Resources Defense Council, Inc. v. Train, 519 F.2d 287 (D.C. Cir. 1975)(agency must make full record available to district court for review). But cf. Doriaswany v. Secretary of Labor, 555 F.2d 832, 842 (D.C. Cir. 1975)(effective judicial review possible without further explanation of agency action).

The Courts of Appeals for the Fifth and Eighth Circuits acknowledge that additional explanation may be required, but have yet to identify such a case and have implied that they will be reluctant to grant requests for additional agency information. See Bank of Commerce v. City Nat'l Bank, 484 F.2d 284, 288 (5th Cir. 1973), cert. denied, 416 U.S. 905 (1974); $\mathscr{c}$. Piedmont Heights Civic Club, Inc. v. Moreland, 637 F.2d 430, 441-42 (5th Cir. 1981) (trial court's finding that failure to state explicitly all cumulative effects of project does not violate the National Environmental Policy Act of 1969 is not reversible error); Madison County Bldg. \& Loan Ass'n v. Federal Home Loan Bank Bd., 622 F.2d 393, 396 (8th Cir. 1980) (Administrative Procedure Act does not require formal findings of fact by agency).

The law in these latter two circuits - the fifth and eighth - is somewhat uncertain. The Courts of Appeals for the Eighth Circuit's seemingly hard-line denial of discovery in the Madison County case, see text accompanying notes 111-24 infra, is undercut somewhat by its earher decision in Independent Meat Packers Ass'n v. Butz, 526 F.2d 228 (8th Cir. 1975), cert. denied, 424 U.S. 966 (1976), in which it noted that it is appropriate in some circumstances to base agency review on a record supplemented by "affidavits, depositions, or other proof of an explanatory nature." Id. at 239 (citations omitted). The court upheld the regulations at issue based on "the administrative record with certain explanatory evidence." Id. at 241. Similarly, the Court of Appeals for the Fifth Circuit in the Bank of Commerce case deujed requests for additional explanation by agency officials but did so under circumstances in which some supplemental explanation had already been demied by the trial court. $484 \mathrm{~F} .2 \mathrm{~d}$ at 288 .

110. 600 F.2d 681 (7th Cir. 1979).

111. 622 F.2d 393 (8th Cir. 1980).

112. 600 F.2d at 693 .

113. 622 F.2d at 398. 
The opinions in these two cases reflect decidedly different attitudes on the extent to which an agency should be expected to explain its decisions. In the City Federal case, the court recognized that it could not establish a precise formula for determining when additional explanation is required."14 The court noted that "the administrative record may show so little controversy that the basis of an agency action is obvious from the record, with no need for an express explanation by the agency."115 On the other hand, when "significant questions were seriously contested" 116 before the agency, the court inust have an explanation that enables it to understand "the connection between the record before it and the choice [the agency] makes."117 Because it thought there was a serious dispute in the case, the court remanded the case and emphasized that:

[c]ourts should not routinely accept agency explanations phrased broadly in terms of the governing statute, "a formal abracadabra to which it has added a few words as a sop to us." To do so would make judicial review "as important as the Statute of Uses which it was said, 'merely added three words to a conveyance." "118

In Madison County the Court of Appeals for the Eighth Circuit, despite similar facts, expressly refused to follow the City Federal holding. The court acknowledged that "it would be helpful to a reviewing court if the Board would provide a nore detailed or nore precise statement of its reasons. . . . But that is very different from saying that effective judicial review will be frustrated without such a statement."119 Noting that each year the Federal Hoine Loan Bank Board processes a large number of new operating charter apphications, the court stated that "[i]t would significantly burden the Board to have to give an indepth explanation of each of its actions merely because judicial review was a possibility." 120 Effective judicial review can be conducted, the court concluded, simply "by coinparing the agency action with the administrative record." 121

Judicial insistence on the perfect explanation when reviewing agency action is precluded by both Overton Park and Camp v. Pitts. ${ }^{122}$ In this sense, the Madison County court's concern about innposing un-

114. $600 \mathrm{~F} .2 \mathrm{~d}$ at 689.

115. Id.

116. Id.

117. Id. at 688.

118. Id. at 693.

119. 622 F.2d at 397 .

120. Id.

121. $I d$.

122. See notes 96-103 supra and accompanying text. 
necessary burdens on the agency was well placed. ${ }^{123}$ Nevertheless, by recognizing that the need for agency explanation varies as a function of the seriousness and complexity of the dispute before the agency, the court in City Federal established a more realistic standard for determining when to require further explanation froin an agency. Although a curt explanation may have been adequate in Camp v. Pitts or even in Madison County, the propriety of more complex decisions cannot be evaluated on the basis of an agency "one-liner." The extent to which the lack of agency explanation frustrates judicial review necessarily varies, therefore, with the nature of the issues and the complexity of the administrative record. Most courts that have considered the need for additional agency explanation have at least implicitly recognized the relationship between the need for agency explanation and the complexity and importance of the issues presented in the case. ${ }^{124}$

If a court is receptive to the need for additional explanation in a particular case, the court must select the most appropriate inethod of obtaining such explanation. Various factors should be considered. First, courts should consider the complexity of the issues decided by the agency. Questions such as whether particular measures are econonncally feasible, ${ }^{125}$ whether an agency's regulatory objective can be achieved through known technology, ${ }^{126}$ and whether highly technical decisions are supported by technical hiterature in the field may not even be understood by the court unless the agency explains its resolution of these issues in some detail.

Second, courts should consider the complexity and length of the administrative record. If the administrative record consists of a roomful of documents, no court should permit the curt explanation approved in Camp v. Pitts. Any effort to review such a record without agency explanation would be at least frustrating, and in inany cases impossible.

Third, courts should examine their own understanding of the issues. This subjective perception has often been determinative of the

123. 622 F.2d at 397 .

124. See, e.g., ASARCO, Inc. v. EPA, 616 F.2d 1153 (9th Cir. 1980).

The subject matter of agency decisionmaking is frequently very complex. For example, the Department of Interior's Office of Surface Mining Reclamation and Enforcement issued 151 pages of regulations concerning coal exploration and surface coal mining, which, because of their technical complexity, required 407 pages of explanation in the agency's preamble to the regulations. 44 Fed. Reg. 14,902-15,463 (1979) (the regulations are codified in 30 C.F.R. $\$ \S 700-800$ (1980)).

125. See Industrial Union Dep't, AFL-CIO v. American Petroleum Inst., 448 U. S. 607, 63959 (1980).

126. See Sierra Club v. Costle, 657 F.2d 298 (D.C. Cir. 1981). 
result. ${ }^{127}$ If the judge thinks he will be unable properly to evaluate agency action without some further explanation, he will be more likely to require such explanation. The subjective factor also includes the court's perception of agency motives in offering only a limited explanation. For example, in City Federal, the court was clearly concerned with the possibility that the agency's lack of explanation represented a tactical decision by the agency to invoke "abracadabra" to avoid searching judicial review. 128

Fourth, courts should consider whether the private litigant's effort to obtain additional explanation is inerely a further effort to cross-examine the agency on the inerits of its decision. Distimctions between discovering the basis for an agency's decision and questioning the validity of the decision are often difficult to draw; discovery on the foriner may inevitably lead to some probing of the latter. But when courts sense that the principal purpose of seeking explanation is to challenge the merits of the agency's decision, they are quick to deny the requested additional explanation. 129

Even with these four considerations in mind, the origmal Camp $v$. Pitts test - whether the agency's lack of explanation "frustrates" judicial review - should remain the principal focus. But because the frustration levels of different courts may vary, the application of a consistent set of principles would result in more uniform judicial treatment of these issues.

(b) Identification of relevant factors not considered by the agency. An issue related to but often confused with the need for agency explanation is the need to determine whether an agency has considered all "relevant factors" in arriving at a decision. 130 If an agency fails to consider relevant facts that are already part of the administrative record, ${ }^{131}$ the court may require further explanation or remand to the agency. ${ }^{132}$

127. See, e.g., Kennecott Copper Corp. v. EPA, 462 F.2d 846, 848-49 (D.C. Cir. 1972).

128. See text accompanying notes 116-18 supra. Other courts have expressed similar suspicions. See, e.g., Gulf Oil Corp. v. Schlesinger, 465 F. Supp. 913 (E.D. Pa. 1979); Texas Medical Ass'n v. Mathews, 408 F. Supp. 303 (W.D. Tex. 1976); A.O. Smith Corp. v. FTC, 403 F. Supp. 1000 (D. Del. 1975).

129. See, e.g., Philadelphia Council of Neighborhood Orgs. v. Coleman, 437 F. Supp. 1341 (E.D. Pa. 1977), affd, 578 F.2d 1375 (3d Cir. 1978); Missouri ex rel. Missouri-St. Louis Metropolitan Airport Auth. v. Coleman, 427 F. Supp. 1252 (D.D.C.), vacated and remanded without opinion sub nom. Missouri ex rel. Missouri-St. Louis Airport Auth. v. Adams, 564 F.2d 600 (D.C. Cir. 1977).

130. See ASARCO, Inc. v. EPA, 616 F.2d 1153 (9th Cir. 1980).

131. Under Overton Park, courts reviewing agency action "nust consider whether the decision was based on a consideration of the relevant factors and whether there has been a clear error of judgment." 401 U.S. at 416.

132. See text accompanying notes 108-29 supra. See, e.g., ASARCO, Inc. v. EPA, 616 F.2d 1153,1160 (9th Cir. 1980). 
The inquiry into whether the agency considered all relevant factors can have another focus, however. In addition to the agency's consideration of relevant factors in the record, courts must often decide whether other relevant factors, not reflected in the record, should also have been considered.133 In nearly all cases, the suppleinentary materials necessary to decide whether additional, nonrecord, relevant factors should have been considered must come from sources outside the agency.

Cases arising under the National Environmental Policy Act (NEPA) ${ }^{134}$ provide a typical example of this issue. In County of Suffolk v. Secretary of the Interior, ${ }^{135}$ the court considered whether an environinental impact stateinent (EIS) prepared by the Departinent of Interior satisfied the requirements of the NEPA. To decide this issue, the court had to determine whether the agency had evaluated certain factors as required by the NEPA. The court permitted inquiry beyond the administrative record, reasoning:

Although the focus of judicial inquiry in the ordinary suit challenging nonadjudicatory, nonrulenaking agency action is whether, given the information available to the decision-maker at the time, his decision was arbitrary or capricious, and for this purpose "the focal point for judicial review should be the administrative record ...", in NEPA cases, by contrast, a primary function of the court is to insure that the information available to the decision-naker includes an adequate discussion of environmental effects and alternatives which can sometimes be determined only by looking outside the administrative record to see what the agency inay have ignored. ${ }^{136}$

In a variety of cases arising under statutes other than the NEPA, courts have undertaken similar analyses. In Association of Pacific Fish-

133. See generally ASARCO, 616 F.2d 1153 (9th Cir. 1980); Association of Pac. Fisheries v. EPA, 615 F.2d 794, 803, 811 (9th Cir. 1980); County of Suffolk v. Secretary of Interior, 562 F.2d 1368 (2d Cir. 1977), cert. denied, 434 U.S. 1064 (1978); Silva v. Lynn, 482 F.2d 1282, 1284 (1st Cir. 1973); Schicke v. Romney, 474 F.2d 309, 317 (2d Cir. 1973); Atchison, T. \& S. F. Ry. v. Callaway, 459 F. Supp. 188, 192-93 (D.D.C. 1978); Hiatt Grain \& Feed, Inc. v. Bergland, 446 F. Supp. 457, 480 (D. Kan. 1978), affd, 602 F.2d 929 (10th Cir. 1979), cert. denied, 444 U.S. 1073 (1980); Missouri ex rel. Missouri-St. Louis Metropohtan Airport Auth. v. Coleman, 427 F. Supp. 1252, 125758 (D.D.C.), vacated and remanded without opinion sub nom. Missouri ex rel. Missouri-St. Louis Metropohtan Airport Auth. v. Adams, 564 F.2d 600 (D.C. Cir. 1977).

134. 42 U.S.C. $\$ \S 4321-4370$ (1976).

135. 562 F.2d 1368 (2d Cir. 1977).

136. Id. at 1384 (emphasis in original) (citations omitted). The Court of Appeals for the Ninth Circuit reached a similar conclusion in $A S A R C O$, Inc. v. $E P A$, in which it reviewed technical questions relating to an EPA pollution-control requirement. 616 F.2d 1153, 1160 (9th Cir. 1980). Another interesting NEPA case is North Slope Borough v. Andrus, 642 F.2d 589 (D.C. Cir. 1980). In that case, the agency directed the court to a supplemental document in the administrative record that the agency claimed would better explain the agency's environmental impact statement (EIS). The court, citing with approval County of Suffolk v. Secretary of Interior, 562 F.2d 1368 (2d Cir. 1977), held that it was appropriate for it to consider "other contemporaneous deliberative materials" to understand the EIS. 542 F.2d at 603. 
eries v. EPA the court accepted certain studies prepared by the plaintiffs that elucidated the factors that the agency should have considered in connection with the issuance of effluent guidelines. ${ }^{137}$ In Schicke $v$. Romney the court permitted additional inquiry to determine whether HUD had considered local community planning - a factor the agency was required by statute to consider - in connection with its approval of a local rezoning action. ${ }^{138}$ In Hiatt Grain \& Feed, Inc. v. Bergland 139 the court admitted evidence concerning the factors that the agency should have considered, asking, "[h]ow is the Court to determine whether all relevant factors were considered in the adniunstrative record without knowing what factors outside the administrative record were not considered in the decisionmaking process?"140

All of these cases suffer, however, fron1 a confusing discussion of the real basis for permitting discovery concerning possible relevant factors not considered by the agency. In soine instances, the "relevant factors" question and the "inadequate agency explanation" question discussed earlier ${ }^{141}$ may be one and the sanie. For exainple, if there is no evidence that the agency considered relevant materials that are in the record, the agency's explanation may be at fault. The court may overcome this deficiency by seeking further explanation from the agency or simply by declaring the agency's action arbitrary and capricious.

A different case arises, however, if the relevant materials are not already a part of the administrative record. The agency presumably did not consider these relevant factors, ${ }^{142}$ and may not even have known of thein. Ordinarily, a private litigant does not try to establish the existence of relevant factors outside the administrative record through discovery from the agency. In inost cases he seeks - through affidavits, commissioned studies, or discovery from third parties - to introduce his own facts to establish the existence and relevance of these factors. When a plaintiff requests to be permitted to present supplementary information, the court should rule on that request, or on discovery requests related to that issue, on the basis of a nuniber of considerations.

137. 615 F.2d 794, 811 (9th Cir. 1980).

138. 474 F.2d 309, 315, 317 (2d Cir. 1973).

139. 446 F. Supp. 457 (D. Kan. 1978).

140. Id. at 467.

141. See text accompanying notes 108-140 supra and accompanying text.

142. Materials that were considered by the agency should have been included in the record. See Pierson v. United States, 428 F. Supp. 384, 392 (D. Del. 1977). 
First, courts should insist on a showing that the agency is specifically required by statute to consider the information the plaintiff claims to be relevant. ${ }^{143}$ If the plaintiff merely suggests that certain information is relevant, but cannot point to a statutory basis for this conclusion, the court should ordinarily deny the request for supplementation unless the request has some other imdependent basis. ${ }^{144}$

Second, the relevant factor at issue should be a group of facts forming a subject area rather than simply one or more relevant facts within a particular subject area. Practically speaking, an agency cannot and is not expected to consider every scrap of factual inaterial related to a particular issue, so its failure to consider one or more individual facts should not be dispositive. If the agency has not addressed an entire area of inquiry mandated by statute, however, suppleinentation to identify that area is appropriate. ${ }^{145}$

Third, the court inust be vigilant not to permit supplementation intended principally to dispute the agency's decision on the merits. The pertinent issue is how the agency arrived at its decision - that is, what factors it considered - and not how it evaluated those factors. The court may have to review the information in question before resolving this issue. Several courts in comparable circumstances have adopted a pohicy of reviewing the relevant materials and then either including them or striking thein froin the record. ${ }^{146}$

(c) Consideration of background materials for the court's benefit. As administrative decisionmaking becomes increasingly complex, courts may not be able to understand, much less evaluate, the coinplexities of the record. In these circumstances, it is appropriate to permit receipt of background materials simply for the purpose of educating the court. Increasingly, courts have been willing to acknowledge their own limitations in complex cases and to permit parties to subımt background materials as an aid to judicial review.

A leading case on this issue is $A S A R C O$, Inc. v. EPA. ${ }^{147}$ The $A S A R C O$ case involved highly technical scientific issues concerning

143. See Motor \& Equip. Mfrs. Ass'n v. EPA, 627 F.2d 1095, 1116-17 (D.C. Cir. 1979), cert. denied, 446 U.S. 952 (1980).

144. $I d$.

145. See text accompanying notes $135-40$ supra.

146. See Hiatt Grain \& Feed, Inc. v. Bergland, 446 F. Supp. 457, 479-80 (D. Kan. 1978), aff d, 602 F.2d 929 (1979), cert. denied, 444 U.S. 1073 (1980); cf. Smithkline Corp. v. FDA, 587 F.2d 1107, 1118-19 (D.C. Cir. 1978). The Smithkline Corp. court reviewed the information because the agency "deliberately prevented the creation of a record." Although normal practice is to accept the "agency's technical expertise and experience," the court may have to order an adjudicatory hearing if it appears there are genuine issues of fact to be resolved. Id.

147. 616 F.2d 1153 (9th Cir. 1980). 
an EPA requirement for stack testing as a pollution-control measure. The district court held a four day trial, which included substantial expert testimony. Although the court of appeals held that the scope of the trial was overbroad, it expressly acknowledged the right of a district court to obtain background information for its own use:

it is both unrealistic and unwise to "straightjacket" the reviewing court with the administrative record. . . . If the reviewing court finds it necessary to go outside the administrative record, it should consider evidence relevant to the substantive inerits of the agency action only for background information [or for other purposes enuinerated in the decision]. ${ }^{148}$

Other courts have followed $A S A R C O$ and have similarly acknowledged the need for background information in appropriate cases. ${ }^{149}$

Although not expressly sanctioned by Overton Park or Camp v. Pitts, the decisions that acknowledge the right of courts to accept background materials seein clearly correct. The absence of such educational materials may frustrate judicial review in the same way as an madequate administrative explanation for decision making. ${ }^{\text {sso }}$ If a judge does not understand factual materials in the record, he will be unable to evaluate effectively the agency's treatment of that inaterial. Background facts can ease this problein.

2. Procedures for Receiving Supplementary Materials - Discovery and Evidentiary Hearings. A court can use a variety of distinct procedural devices, both adversarial and nonadversarial, to receive supplementary materials that explain or clarify the record. These procedural devices include: (1) remand to the agency; (2) evidentiary hearings; (3) discovery; and (4) receipt of written inaterials.

Remand is the nonadversarial procedure the courts use unost frequently. ${ }^{151}$ On remand the agency inay be required to explain its ac-

148. Id. at 1160 .

149. See, e.g., Denver v. Bergland, 517 F. Supp. 155 (D. Colo. 1981); Hiatt Grain \& Feed, Inc. v. Bergland, 446 F. Supp. 457,467 (D. Kan. 1978)(allowing the parties to present evidence that "merely serves the purpose of assisting the court to understand complex issues presented"). Although courts have accepted this principle, they have resisted its expansion to permit a collateral attack on the agency's decision on the merits and have refused further inforination if the record is sufficiently clear. See Environmental Defense Fund, Inc. v. Costle, 657 F.2d 275, 285 (D.C. Cir. 1981).

150. Although only a few courts have expressly recognized the doctrine of permitting background materials to be introduced, courts have achieved the same result in some cases simply by ordering that a trial be conducted. See, e.g., CF\&I Steel Corp. v. Economic Dev. Admin., 624 F.2d 136 (10th Cir. 1980) (an administrative record case in which a full trial was conducted without any apparent objection); Atchison, T. \& S. F. Ry. v. Alexander, 480 F. Supp. 980 (D.D.C. 1979).

151. See City Fed. Sav. \& Loan Ass'n v. Federal Home Loan Bank Bd., 600 F.2d 681 (7th Cir. 1979); Dry Color Mfrs. Ass'n v. Department of Labor, 486 F.2d 98 (3d Cir. 1973); Schicke v. Romney, 474 F.2d 309 (2d Cir. 1973); Kemmecott Copper Corp. v. EPA, 462 F.2d 846 (D.C. Cir. 
tion further or to state whether it considered newly identified "relevant factors." If the agency explanation is inadequate or if other considerations still justify adversarial procedures, these can be implemented after remand. Instead of remanding, a number of courts have required either adversarial or nonadversarial evidentiary hearings to obtain clarifying or explanatory materials to supplement the record. ${ }^{152}$ Non trialtype evidentiary hearings can take different forins, and may mvolve accepting affidavits or testimony (without cross-examination). ${ }^{153}$ In contrast, adversarial hearings involve testimony and are used in cases in which there is too great a possibility that the agency's post hoc explanation would be self-serving. 154

If the court recognizes the need for adversarial procedures, particularly if it anticipates a hearing, it may also permit solne discovery. ${ }^{155}$ In certain cases, the parties may be able to expedite inatters by agree$\mathrm{mg}$, following discovery, to the submission of written materials without a hearing. In any event, discovery often sharpens the issues prior to their eventual submission to the court.

Fimally, in heu of any of the foregoing, courts often accept plaintiffs' submission of a written study or other memoranda to identify relevant factors overlooked by the agency or to provide background

1973); cf. First Bank \& Trust Co. v. Smith, 545 F.2d 752 (1st Cir. 1976) (the court of appeals had remanded to the district court to determine whether the Comptroller of the Currency had used the proper state law standard im approving a bank branch application. The court of appeals approved the district court's cousideration of the Comptroller's supplemental opimion, which indicated that the proper state law standard had been applied.).

152. See National Nutritional Foods Ass'n v. Mathews, 557 F.2d 325 (2d Cir. 1977); National Nutritional Foods Ass'n v. Weinberger, 512 F.2d 688 (2d Cir. 1975); St. Joseph's Hosp. v. Blue Cross, 489 F. Supp. 1052 (S.D.N.Y. 1979); National Nutritional Foods Ass'n v. Mathews, 418 F. Supp. 394 (S.D.N.Y. 1976), affd, 557 F.2d 325 (2d Cir. 1977).

153. See Camp v. Pitts, 411 U.S. 138, 143 (1973). In the cases in which a circuit court had remanded for a "hearing," the district court has deemed it appropriate simply to accept affidavits from the agency decisionmaker. See National Nutritional Foods Ass'n v. Mathews, 557 F.2d 325 (2d Cir. 1977)(approving the court's decision not to require live evidence); National Nutritional Foods Ass'n v. Wemberger, 512 F.2d 688 (2d Cir. 1975); Shicke v. Romney, 474 F.2d 309 (2d Cir. 1973); National Nutritional Foods Ass'n v. Mathews, 418 F. Supp. 394 (S.D.N.Y. 1976); Schicke v. Lynn, 386 F. Supp. 97 (D. Conn.), aff d, 507 F.2d 1389 (2d Cir. 1974).

154. See, e.g., Piedmont Heights Civic Club, Inc. v. Moreland, 637 F.2d 430 (5th Cir. 1981) (testimony received during preliminary-imjunction hearing); ASARCO, Inc. v. EPA, 616 F.2d 1153 (9th Cir. 1980); Independent Meatpackers Ass'n v. Butz, 526 F.2d 228 (8th Cir. 1975), cert. denied, 424 U.S. 966 (1976); Hospital Ass'n v. Toia, 473 F. Supp. 917 (S.D.N.Y. 1979); Gulf Oil Corp. v. Schlesinger, 465 F. Supp. 913 (E.D. Pa. 1979).

155. See Natural Resources Defense Council, Inc. v. Train, 519 F.2d 287, 292 (D.C. Cir. 1975); A.O. Smith Corp. v. FTC, 403 F. Supp. 1000, 1015 (D. DeL. 1975); Community Sav. \& Loan Ass'n v. Federal Home Loan Bank Bd., 68 F.R.D. 378, 381-82 (E.D. Wis. 1975). But cf. Bank of Commerce v. City Nat'l Bank, 484 F.2d 284, 287 (5th Cir. 1973)(Comptroller is not required to hold an adversary hearing in passing upon bank charter applications.) 
information. ${ }^{156}$ The court may consider the materials directly as an aid to the decisionmaking process, ${ }^{157}$ or may request that the agency make an initial evaluation of the materials and report back to the court. ${ }^{158}$

Although the decision as to the appropriate procedures varies with the particular facts before the court, that decision will always involve the determination of whether adversarial or nonadversarial factfindimg procedures are most appropriate. It is difficult to formulate general rules to govern this choice; considerations include the precise nature of possible adversarial or nonadversarial procedures, the importance of the issues, the degree to which the court is skeptical of receiving reliable information from the agency without cross-examination of agency personnel, and the stage of the proceeding.

Courts should be guided by two general primciples, lowever, when resolving this issue. First, courts need not always immediately decide between adversarial and nonadversarial alternatives because the metlods may be used consecutively. For example, a request for agency affidavits or a remand to the agency for submission of further written materials does not foreclose the court from subsequently ordering additional adversarial factfinding if the affidavits or supplemental information on remand proves unsatisfactory.

The use of nonadversarial and adversarial procedures consecutively has two primcipal advantages. First, nonadversarial procedures may be sufficient to resolve the issue; if so, time is saved and costs are reduced. Second, nonadversarial procedures are more consonant with the general goal of limiting judicial review to written materials received from the agency because materials received as a result of nonadversarial affidavits or remand are often similar to materials already in the administrative record. Thus, nonadversarial procedures cause the least imtrusion into areas of agency discretion. Of course, if the supplementary material that is received is a further explanation from the agency, the risk of post loc rationalization may mcrease the need for follow-up adversarial procedures. 159

The second primciple governing the selection of nonadversarial or adversarial procedures is that courts need not protect agency decisionmakers from adversarial cross-examination concerning facts that

156. See Association of Pac. Fisheries v. EPA, 615 F.2d 794, 811 (9th Cir. 1980); Portland Cement Ass'n v. Ruckleshaus, 486 F.2d 375, 393 (D.C. Cir. 1973).

157. See Association of Pac. Fisheries v. EPA, 615 F.2d at 811-12.

158. On review of rulemaking, courts have remanded the particular regulation or decision to the agency with instructions that the agency consider the plaintiffs written submission and report to the court within a specific time period. See Portland Cement Ass'n v. Ruckleshaus, 486 F.2d 375 (D.C. Cir. 1973); In re Surface Mining Regulation Litig., 452 F. Supp. 327 (D.D.C. 1978).

159. See notes 176-82 infra and accompanying text. 
do not involve the decisionmakers' mental processes. ${ }^{160}$ Courts need not presume that a decisionmaker's mental processes invariably will be at issue. ${ }^{161}$ The smaller the threat that adversarial procedures will be focused on predccisional deliberations, the more willing courts should be to permit adversarial proceedings. It is frequently difficult for the courts to apply this distmction. Nevertheless, wlien the risk of disclosing mental processes is low, adversarial methods may be the best way to conduct the necessary factfinding. In any event, courts should issue specific orders to control the scope of discovery and to protect sensitive areas from unnecessary imquiry. ${ }^{162}$

3. Scrutiny of Post Hoc Rationalizations. A furtler issue often confronts the court when it receives explanatory materials to supplement the administrative record. When the Supreme Court in Overton Park suggested that a district court may im appropriate circumstances require further explanation from an agency, the Court cautioned that "[s]ucl an explanation will, to some extent, be a 'post hoc rationalization' and thus must be viewed critically." 163 Although the lower courts have readily parrotted this warning, ${ }^{164}$ the identification and application of meaningful standards for review of post lioc rationalizations lias

160. See notes 85-92 supra and accompanying text.

161. An examination of a decisionmaker's explanation for his decision, for example, can in some cases be conducted without probing actual thought processes, for instance, by examining what was decided rather than how the decision was reached.

162. Courts should be particularly willing to permit adversarial investigation of issues not involving mental processes when the investigation can be conducted through discovery rather than by a hearing. The court is not bound to consider the results of discovery if the discovery is conducted improperly or produces irrelevant infornation. Under the Federal Rules, the scope of discovery is considerably broader (under Rule 26) than the scope of admissible evidence. In addition, if third persons rather than agency employees propose discovery, the risk of disclosure of the agency's mental processes may be reduced even further. But $c f$. Lukens Steel Co. v. Kreps, 477 F. Supp. 444 (E.D. Pa. 1979), rev'd on other grounds sub nom. Lukens Steel Co. v. Klutznick, 629 F.2d 881 (3d Cir. 1980).

163. 401 U.S. at 420 . The differences between contemporaneous and post hoc agency explanations are real. In most agencies, the contemporaneous explanation is drafted by bureaucrats imvolved in the decision making process. Once hitigation has commenced, however, the agency's lawyers inevitably are involved in any further agency statements. When a court orders or requests supplemental explanation, the agency personnel drafting that explanation will seek advice from the agency's lawyers. The basis for the private litigant's challenge to agency action will by this time have been disclosed, and agency personnel will know specifically what weaknesses in the agency's position must be addressed. The agency in most cases will respond precisely to the litigant's contentions in the supplemental explanation and ensure that the response is properly phrased based on a detailed legal review. Under these circumstances, a more critical review of agency action scems appropriate.

164. See, e.g., Piedmont Heights Civic Club, Inc. v. Moreland, 637 F.2d 430, 439-40 (5th Cir. 1981); City Fed. Sav. \& Loan Ass'n v. Federal Home Loan Bank Bd., 600 F.2d 681, 689-90 (7th Cir. 1979); First Bank \& Trust Co. v. Smith, 545 F.2d 752, 753 (1st Cir. 1976), cert. denied, 430 U.S. 931 (1977); Lukens Steel Co. v. Kreps, 477 F. Supp. 444 (E.D. Pa. 1979), rev'd on other grounds sub nom. Lukens Steel Co. v. Klutznick, 629 F.2d 881 (3rd Cir. 1980). 
proven difficult.165 The two most troublesome problems have been determining what constitutes a post hoc rationalization and determining how to apply the Supreme Court's admonition that such rationalizations "be viewed critically."

(a) What is a post hoc rationalization? If the administrative record before the court includes no explanation of the agency's action, Overton Park clearly mandates that a subsequently developed explanation be considered a post hoc rationalization. ${ }^{166}$ Most courts obtam the agency's after the fact explanation by remanding the action to the agency. ${ }^{167}$ Use of the remand procedure does not alter the basic post hoc character of the agency's supplemental explanation, however, as at least one court has recognized. ${ }^{168}$

Surprisimgly, however, at least two courts have held that an agency supplementation of its explanation on remand is not a post hoc rationalization within the meaning of Overton Park. In Lukens Steel Co. $v$. Kreps, after initially reversing the agency and remanding for further action, the district court im a second opinion ${ }^{169}$ held that the agency's supplemental explanation on remand did not constitute a post hoc rationalization and therefore was not appropriate for special scrutiny. ${ }^{170}$ Similarly, in First Bank and Trust Co. v. Smith, the court of appeals, after previously remanding to the district court to obtain a statement from the agency as to whether a particular relevant factor had been considered, held that the agency's suppleniental statement was not a

165. See generally The Supreme Court, 1970 Term, 85 HARv. L. Rev. 3, 320-23 (1971).

166. 401 U.S. at 420.

167. On remand, the court retains jurisdiction and may establish a deadline for submission of the agency's explanation. See generally cases cited at note 164 supra.

168. See City Fed. Sav. \& Loan Ass'n v. Federal Home Loan Bank Bd., 600 F.2d 681, 689-90 (7th Cir. 1979) (holding that when agency explanation is inadequate to permit judicial review, remand is appropriate even though the agency explanation on remand "will to some extent constitute 'post hoc rationalizations' and for that reason be subject to more critical review") (citing Overton Park).

169. 477 F.Supp. 444, 446 (E.D. Pa. 1979).

170. 482 F. Supp. 736 (E.D. Pa. 1979), rev'd on other grounds sub nom. Lukens Steel Co. v. Klutznick, 629 F.2d 881 (3d Cir. 1980), see generally Lukens Steel Co. v. Kreps, 477 F.Supp. 444, 448-51 (E.D. Pa. 1979) (discussion prior to remand about scope of judicial review of agency action). In Lukens Steel, the district court set aside a decision by the Economic Development Administration of the Departmeut of Commerce to grant financial assistance to a failing steel company. The court found that although the agency acted within the scope of its authority in granting assistance, its action was arbitrary and capricious. Because the agency's action was not supportable on the record, the court remanded the action to the agency for further explanation. Id. On remand, the agency issued a clarifying explanation and again sought to extend financial assistance. The case reached the district court again and the agency action was upheld. On appeal, however, this second decision was reversed and the agency action was again declared arbitrary and capricious. See Lukeus Steel Co. v. Klutznick, 629 F.2d 881 (3d Cir. 1980). 
post hoc rationalization. ${ }^{171}$ Neither the Lukens Steel court nor First Bank court articulates any reason for refusing to characterize the agency's supplemental explanation as a post hoc rationalization. ${ }^{172}$ Both holdings seem mcorrect because under the seemingly clear language of Overton Park, any explanation for agency action that is developed after the fact on remand is post hoc. ${ }^{173}$ That the court specifically requests the supplemental explanation, as in First Bank, or that the supplemental proceedings at the agency are intended to correct agency action previously declared arbitrary and capricious, as in Lukens Steel, does not alter the post hoc character of the supplemental explanation.

Recently, another court has suggested that apphication of the post hoc label to a noncontemporaneous agency explanation may depend on whether the subsequent explanation is obtained on remand or through a hearing. In Piedmont Heights Civic Club, Inc. v. Moreland ${ }^{174}$ the court held that the Overton Park stricture against post hoc rationalization does not apply when the decisionmakers actually testify. ${ }^{175}$ If this imterpretation of Overton Park is correct, courts may avoid the post hoc problem entirely simply by receiving live testimony rather than remanding to the agency. The availability of cross-examination should ensure that the agency's noncontemporaneous explanation is subject to real scrutiny.

(b) Procedures for scrutinizing post hoc rationalizations. A court should not, of course, ignore a supplemental explanation because it is post hoc. Overton Park cautions merely that post hoc rationalizations "must be viewed critically." 176 In dealing critically with post hoc rationalizations, a court has three options. First, the court could attempt to implement a more stringent standard of review. ${ }^{177}$ Under

171. 545 F.2d 725 (1st Cir. 1976). The court reached this conclusion even though a new agency head who had taken office in the interim had no direct knowledge about the considerations underlying the original agency decision. Id. at 753 .

172. The First Bank court stated simply: "we think the Coinptroller's assertion that the relevant standard 'was considered' coupled with his reiterated approval of the application in light of the Massachusetts statute is sufficient to establish that his decision was in accordance with law.' " $545 \mathrm{~F} .2 \mathrm{~d}$ at 753 .

173. See Citizens to Preserve Overton Park Inc. v. Volpe, 401 U.S. 402, 420 (1971).

174. 637 F.2d 430 (5th Cir. 1981).

175. Plaintiffs cliallenged a series of highway projects on the ground that the projects had been improperly grouped for purposes of the environmental impact statements (EIS). On a hearing for a preliminary injuuction, the district court heard testimony from government officials concerning why the projects had been so grouped. When the preliminary injunction was denied, plaintiffs appealed and asserted that the district court liad improperly relied on the agency's post hoc rationalizations. 637 F.2d at $439-40$.

176. 401 U.S. at 420.

177. The Lukens Steel court considered but rejected this approach, concluding that the agency action was not a post hoc rationalization. $482 \mathrm{~F}$. Supp. at 738. 
Overton Park, however, the district court is already required to conduct a "thorough, probing, in depth review" encompassing a "searching and careful" inquiry into the facts. ${ }^{178}$ Moreover, the ultimate legal standard for revicw - whethcr the agency action was "arbitrary and capricious" - is inandated by a governing statute, usually the APA. ${ }^{179}$ It is difficult to imagine what more stringent review standard imght be adopted. Although soine courts inay prefer simply to recite Overton Park's suggestion that post hoc rationalizations be judged "critically," the probleins of defining and implementing that term are substantial. ${ }^{180}$

The adversarial process of discovery provides a second method of critically examining post hoc rationalizations. ${ }^{181}$ Discovery affords the private litigant, and therefore the court, an opportunity to probe critically the basis for the agency's supplemental explanation. Under this approach, the ultimate standard of review is still the arbitrary and capricious standard, but suppleinental materials can be submitted to the court to enhance the court's ability to measure agency action against that standard. Thus, a court should be much more willing to permit discovery, at least of a limited scope, when an agency relies on a post hoc explanation of its decision. ${ }^{182}$

The third approach is simply to follow Piedmont Heights Civic Club, Inc. v. Moreland 183 and accept live testimony from agency decisionmakers. Piedmont Heights Civic Club held that this approacis avoids the post hoc characterization altogether. ${ }^{184}$ Even if such testiunony is considered a post hoc rationalization, the availability of crossexamination should satisfy the Supreme Court's requirement that such testimony be evaluated critically.

178. 401 U.S. at 415, 416. See 3 K. Davis, Administrative Law Treatise $§ 17.4$ (2d ed. 1979).

179. 5 U.S.C. 8706 (2)(A) (1976).

180. At least one court, in dictum, has suggested that Overton Park mandates a more critical standard of review. See City Fed. Sav. \& Loan Ass'n v. Federal Home Loan Bank Bd., 600 F.2d 681, 689-90 (7th Cir. 1979).

181. In both First Bank and Lukens Steel, discovery sought by the private hitigant was denied on the ground that the agency action did not constitute a post hoc rationalization. First Bank \& Trust Co. v. Smith, 545 F.2d 752, 753 (1st Cir. 1976), cert. denied, 430 U.S. 931 (1977); Lukens Steel Co. v. Kreps, 477 F. Supp. 444 (E.D. Pa. 1979), rev'd on other grounds sub nom. Lukens Steel Co. v. Klutznick, 629 F.2d 881 (2d Cir. 1980).

182. See note 163 supra.

183. 637 F.2d 430 (5th Cir. 1981).

184. See text accompanying note 175 , supra. 


\section{Ensuring the Integrity of the Decisionmaking Process - Proscription of Improper Behavior.}

In addition to the affirmative obligations that courts impose on agencies regarding the compilation of the administrative record and the explanation of agency action, ${ }^{185}$ the courts have established proscriptive rules designed to ensure the integrity of the decisionmaking process. These rules prohibit certain types of agency behavior that violate basic principles of procedural fairness, ranging froin improper congressional influence to actions in violation of the agency's own regulations. They relate to the procedure used in reaching the decision rather than the substantive validity of the decision itself. Agency action that runs afoul of these proscriptions is inconsistent with law, and should be set aside on review. ${ }^{186}$

Because agency transgressions may not always be reflected in the administrative record, private litigants frequently seek discovery or additional factfinding to uncover the details of possible improprieties. In responding to these requests, the courts must balance the need for a inethod to docuinent genuine misdeeds with a proper reluctance to impinge on the privileged area of the decisionmaker's mental processes. As a general rule, courts have required some prina facie showing of impropriety before granting a private litigant's request for additional discovery or factfinding.

1. Examples of Improper Agency Behavior.

(a) Improper congressional influence. Courts have the power to set aside agency action that is the product of improper congressional interference. 187 Open congressional hearings, usually in the forn of "oversight" hearings, as well as surreptitious backroom lobbying may

185. See text accompanying notes 53-184 supra.

186. The agency decisionmaking procedure may be constrained by the fifth amendment due process clause, by statutes or regulations governing the agency in questiou, or by the APA. The APA states that: "[T] he reviewing court shall . . hold unlawful and set aside agency actions . . . found to be (A) arbitrary, capricious, an abuse of discretion, or otherwise not in accordance with law; (B) contrary to constitutional right, power, privilege or immunity; . . . [or] (D) without observance of procedure required by law." 5 U.S.C. $\$ 706$ (1976) (einphasis added).

187. See generally American Pub. Gas Ass'n v. Federal Power Comm'n, 567 F.2d 1016, 106970 (D.C. Cir. 1977), cert. denied, 435 U.S. 907 (1978); Gulf Oil Corp. v. Federal Power Comm'n, 563 F.2d 588, 610-12 (3d Cir. 1977), cert. denied, 434 U.S. 1062 (1978); District of Columbia Fed'n of Civic Ass'ns v. Volpe, 459 F.2d 1231, 1245-48 (D.C. Cir. 1971), cert. denied, 405 U.S. 1030 (1972); SEC v. Wheeling-Pittsburgh Steel Corp., 482 F. Supp. 555 (W.D. Pa. 1979) (en banc), vacated, 648 F.2d 118 (3d. Cir. 1981); Texas Medical Ass'n v. Mathews, 408 F. Supp. 303, 306-07 (W.D. Tex. 1976); Pillsbury Co. v. FTC, 354 F.2d 952 (5th Cir. 1966); cf. Sun Oil Co. v. United States, 572 F.2d 786, 812-13 (Ct. Cl. 1978) (White House inferference). On improper agency action see generally Texas Oil \& Gas Corp. v. Andrus, 498 F. Supp. 668 (D.D.C. 1980); Shell Oil Co. v. DOE, 477 F. Supp. 413 (D. Del. 1979); Environmental Defense Fund, Inc. v. Blum, 458 F. Supp. 650 (D.D.C. 1978). 
constitute improper congressional meddling. ${ }^{188}$ Because the line between proper and improper congressional imfluence is difficult to draw, the showimg of congressional interference must be compelling. Congressional action may be "regrettable and quite mconsistent with that due regard for the independence of the [agency] which Congress and the courts must maintam," 189 and yet not be grounds for overturning agency action. The private hitigant inust demonstrate the probability, rather than the mere possibility, that congressional intervention improperly influenced agency action. 190

(b) Ex parte contacts with the agency during rulemaking. Ex parte contacts that occur during infornal rulemaking and have the effect of depriving the public of the right to participate meaningfully in the decisionmaking process are grounds for overturning the agency action. ${ }^{191}$ Ordinarily, the agency may cure the taimt of ex parte contacts by placing a summary of the contacts in the public file so that interested persons may comment on them. ${ }^{192}$ In identifying ex parte contacts, however, difficult issues may arise involving the extent to which interagency contacts are subject to the ex parte doctrine and the identification of the point at which rulemaking, which triggers the doctrine, commences. ${ }^{193}$

(c) "Bad faith" action by the agency. A rather amorphous restriction on agency decisionınaking is the rule prohibiting "bad faith" on

188. For example, in Pillsbury Co. v. FTC, 354 F.2d 952 (5th Cir. 1966), congressional "oversight" hearings for the purpose of cross-examining agency decisionmakers on a matter currently before the agency were held to constitute improper congressional inteference. See also District of Columbia Fed'n of Civic Ass'ns v. Volpe, 459 F.2d 1231 (D.C. Cir. 1971), cert. denied, 405 U.S. 1030 (1972); SEC v. Wheeling-Pittsburgh Steel Corp., 482 F. Supp. 555 (W.D. Pa. 1979), vacated, $648 \mathrm{~F} .2 \mathrm{~d} 118$ (3d Cir. 1981) (en banc) (the district court, in a ruling subsequently vacated by a panel of the circuit court, quashed SEC subpoenas on the grounds that the SEC investigation had been prompted by improper political intervention by Senator Lowell Weicker or his staff). See generally United States v. Fensterwald, 553 F.2d 231 (D.C. Cir. 1977).

189. American Pub. Gas Ass'n v. Federal Power Comm'n, 567 F.2d 1016, 1070 (D.C. Cir. 1977), cert. denied, 435 U.S. 907 (1978).

190. Id.; Texas Oil \& Gas Corp. v. Andrus, 498 F. Supp. 668 (D.D.C. 1980).

191. See generally Bethlehen Steel Corp. v. EPA, 638 F.2d 994 (7th Cir. 1980); Raz Inland Navigation Co. v. ICC, 625 F.2d 258 (9th Cir. 1980); National Sinall Shipments Traffic Conference, Inc. v. ICC, 590 F.2d 345 (D.C. Cir. 1978); United States Lines, Inc. v. Federal Maritime Comm'n, 584 F.2d 519 (D.C. Cir. 1977); Honie Box Office, Inc. v. FCC, 567 F.2d 9, $55-57$ (D.C. Cir.), cert. denied, 434 U.S. 829 (1977); Environmental Defense Fund, Inc. v. Blunl, 458 F. Supp. 650 (D.D.C. 1978).

192. Hoine Box Office, Inc. v. FCC, 567 F.2d 9, 57 (D.C. Cir.), cert. denied, 434 U.S. 829 (1977); In re Permanent Surface Mining Regulation Litig., 13 Env't Rep. Cas. (BNA) 1586 (D.D.C. 1980).

193. See In re Permanent Surface Mining Regulation Litig., 13 Env't Rep. Cas. (BNA) 1586 (D.D.C. 1980). 
the part of the decisionmaker. ${ }^{194}$ For example, a six year delay by an agency in taking final administrative action was held to constitute bad faith, ${ }^{195}$ but a showing that the decisionmaker had only been in office for a short time and that he inay not have adequately reviewed the record before making his decision was held imsufficient to establish "bad faith." 196 Allegations that the decisionmaker was biased may also involve bad faith claims. ${ }^{197}$

(d) Actions in violation of agency regulations. As a general rule, an agency is bound by its own regulations, and courts have overturned agency actions that were in violation of the applicable regulations. ${ }^{198}$ In the leading case of United States ex rel. Accardi v. Shaughnessy, ${ }^{199}$ the Supreme Court held that once the Attorney General had by regulation delegated his authority over deportation cases to the Board of Immigration Appeals, he was prohibited from exercising that authority himself by dictating the outcome of a particular case. Essential to the Court's decision was the conclusion that once the Attorney General had promulgated binding regulations of general effect, he could not depart from those regulations in individual cases. ${ }^{200}$ Several subsequent cases have confirmed this general principle, ${ }^{201}$ including United

194. See Citizens to Preserve Overton Park, Inc. v. Volpe, 401 U.S. 402 (1971); Bethlehem Steel Corp. v. EPA, 638 F.2d 994, 1000 (7th Cir. 1980); National Nutritional Foods Ass'n v. FDA, 491 F.2d 1141 (2d Cir. 1974); Atchison T. \& S. F. Ry. v. Alexander, 480 F. Supp. 980 (D.D.C. 1979); Abbott Laboratories, Inc. v. Harris, 481 F. Supp. 74 (N.D. Ill. 1979); cf. KFC Nat'1 Mgmt. Corp. v. NLRB, 497 F.2d 298, 305 (2d Cir. 1974)(on prima facie demonstration of impropriety, court will inquire into the administrative process to ensure that the decisionmaking was informed, unbiased, and personal); see also The Supreme Court, 1970 Term, 85 HARv. L. REv. 3, 321 (1971).

195. Abbott Laboratories Inc. v. Harris, 481 F. Supp. 74 (N.D. Ill. 1979).

196. National Nutritional Foods Ass'n v. FDA, 491 F.2d 1141 (2d Cir. 1974).

197. See Getty Oil Co. v. DOE, [1978] ENERGY MGMT. (CCH) I] 9741 (D. Del. May 4, 1978).

198. A related issue inay arise when governmeut einployees are sued in their individual capacity. In Larson v. Dounestic \& Foreign Commerce Corp., 337 U.S. 682 (1949), the Supreine Court stated that it would permit such suits if the federal official had acted outside his statutory or constitutional authority. Id. at 698-99. Prior to 1976, such actions against officials in their individual capacity were a relatively frequeut device for avoiding the doctrine of sovereign immunity that otherwise barred suit to enjoin federal agency action. In 1976, however, the APA was amended to remove the sovereign immunity bar if suit against a federal ageucy was otherwise proper. 5 U.S.C. $\$ 702$ (1976). It is therefore less important today to enjom agency officials in their individual capacities. Nevertheless, discovery may be appropriate in actions against individual federal officials to determine the extent to which unlawful action was taken. See Land v. Dollar, 330 U.S. 731 (1947). Although the Land case was tacitly disapproved in other respects by Larson, the holding on the propriety of discovery may remain viable.

199. 347 U.S. 260 (1954).

200. Id. at 267.

201. See, e.g., Yellin v. Umited States, 374 U.S. 109 (1963); Vitarrelli v. Seaton, 359 U.S. 535 (1959); Service v. Dulles, 354 U.S. 363 (1957); Scanwell Laboratories v. Shaffer, 424 F.2d 859, 874 (D.C. Cir. 1970) (agency regulations have the force of law and are not purely discretiouary). This general rule is subject to exceptions, particularly when a regulation is intended to govern internal agency procedures rather than to protect public interests. See, eg., American Farm Limes v. Black 
States v. Nixon, in which the Supreme Court held that the President was bound by the Attorney General's regulation that granted to the special prosecutor the power to contest the President's assertion of executive privilege. ${ }^{202}$ Thus, although generally an agency is free to revoke a regulation, it is not free to ignore a properly promulgated regulation in individual cases. ${ }^{203}$

2. Discovery and Other Factfinding. Procedures for Assessing Improper Agency Conduct. Whatever the nature of the impropriety alleged, courts traditionally have been careful not to allow inere allegations of bad faith or improper action to give rise to undesirable "fishing expeditions" into the conduct of agency and congressional officials. Courts have imsisted on some preliminary showing of impropriety before permitting investigation of possible impropriety through discovery or other procedures. ${ }^{204}$ Two issues confront courts in such situations: (1) what kind of showing should be required to trigger a private hitigant's discovery or other factfindimg rights, and (2) if an appropriate showing is made, what sort of discovery or other factfinding is appropriate $\mathrm{m}$ the particular case.

Ball Freight Serv., 397 U.S. 532, 539 (1970); United States v. Lockyer, 448 F.2d 417, 421 (10th Cir. 1971); Sun Oil Co. v. Federal Power Comm'n, 256 F.2d 233, 239 (5th Cir. 1958); NLRB v. Grace Co., 184 F.2d 126, 129 (8th Cir. 1950); see Berger, Do Regulations Really Bind Regulators? 62 Nw. U. L. REv. 137 (1967); Sofaer, Judicial Control of Informal Discretionary Adjudication and Enforccment, 72 Colum. L. Rev. 1293, 1319-31 (1972); Note, Violation by Agencies of Their Own Regulations, 87 HARV. L. Rev. 629 (1974).

202. United States v. Nixon, 418 U.S. 683 (1974).

203. A major application of this principle arises in cases contesting the award of government contracts. In Scanwell Laboratories, Inc. v. Shaffer, 424 F.2d 859, 874 (D.C. Cir. 1970), the Court of Appeals for the District of Columbia Circuit ruled that a frustrated bidder had standing to challenge the award of a government contract to an allegedly nonresponsive bidder. In reaching this conclusion, the court declared:

The regulations of the Federal Aviation Administration have the force of law. The procurement regulations also have the force of law. When a prima facie showing of the violation of those regulations has been nuade the agency may not be heard to say that the matter in question has been left to its discretion.

424 F.2d at 874 (citations ommitted).

Subsequent cases have emphasized that although procurement decisions may be challenged if they contravene specific regulations or statutes, the factual conclusions reached by procurement officials must be upheld unless they are arbitrary and capricious. Steinthall \& Co. v. Seannans, 455 F.2d 1289 (1971); Wheelabrator Corp. v. Chaffee, 455 F.2d 1306 (D.C. Cir. 1971). Thus, one who is adversely affected by the award of a government contract may challenge a procurement position if he shows that either "(1) the procurement official's decision on mattcrs coinunitted primarily to his own discretion had no rational basis, or (2) the procurement procedure involved a clear and predjudicial violation of applicable statute or regulations." Kentron Hawaï Ltd. v. Warner, 480 F.2d 1166, 1169 (D.C. Cir. 1973).

Where the plaintiff alleges that the procurement official violated a specific statute or rcgulation, the administrative record may not provide an adequate basis upon which to review the official's action. Therefore, some additional fact finding may be necessary.

204. Sierra Club v. Costle, 657 F.2d 298, 390, n.450 (D.C. Cir. 1981). 
The nature of the showing required to trigger discovery should vary as a function of both the type of impropriety alleged and the nature of the discovery requested. When concerns about the morahty or ethics of the decisionmaker's action are involved, as in cases of alleged bad faith, bias or improper congressional interference, courts usually require a stronger preliminary showing before permitting factfinding on the issue. ${ }^{205}$ Courts have variously required a "strong showing,"206 a "prima facie demonstration of impropriety," 207 or a showing of "special circumstances." 208

The requirement of a "strong showing" derives from the series of Supreme Court decisions in United States v. Morgan. ${ }^{209}$ In the last of its four Morgan decisions, the Court equated agency decisionmaking with judicial decisionmaking and noted that scrutiny of the mental processes of the former is just as undesirable as scrutiny of a judge's mental processes. ${ }^{210}$ On the theory that cross-examination of agency decisionmakers is just as undesirable as cross-examinination of judges, the Court prohibited scrutiny of the agency decisionmaker's reasoning process ${ }^{211}$ absent what the Court in Overton Park subsequently defined as a "strong showing of bad faith or improper behavior."212

The general apphicability of Morgan $I V$ to informal agency action is questionable in two respects. First, Morgan $I V$ involved agency adjudication. Informal nonadjudicatory action may not require the same degree of protection of executive agency thought processes. Second, the "strong showing" requirement was specifically established in Morgan $I V$ as a precondition to taking testimony from agency decisionmakers. The development of facts relevant to claims of congressional influence or bad faith action would not always require such testimony. Factfinding merely to identify information provided to an agency by congressional representatives or through ex parte contacts will not reveal the mental processes of the agency decisionmaker; because discovery of such information is relatively unintrusive on the agency decisionmaker, the showing required to obtain that discovery should be reduced.

205. See, e.g., Environmental Defense Fund, Inc. v. Blum, 458 F. Supp. 650, 663 (D.D.C. 1978).

206. Sierra Club v. Costle, 657 F.2d 298, 390 n.450 (D.C. Cir. 1981); Environmental Defense Fund, Inc. v. Blum, 458 F. Supp. 650, 663 (D.D.C. 1978).

207. KFC Nat. Mgmt. Corp. v. NLRB, 497 F.2d 298, 305 (2d Cir. 1974).

208. SEC v. Dresser Indus., 628 F.2d 1368, 1388 (D.C. Cir.), cert. denied, 449 U.S. 993 (1980).

209. There were four Morgan decisions: Morgan v. Umited States, 298 U.S. 468 (1936) (Morgan I); Morgan v. Umited States, 304 U.S. 1 (1938) (Morgan II); Umited States v. Morgan, 307 U.S. 183 (1939) (Morgan III); United States v. Morgan, 313 U.S. 409 (1941) (Morgan IV).

210. 313 U.S. at 422 .

211. Id.

212. Citizens to Preserve Overton Park, Inc. v. Volpe, 401 U.S. 402, 420 (1971). 
Even when the requisite strong showing of improper agency conduct is inade, courts should permit only the least intrusive method of factfinding to analyze the improper conduct. Affidavits or limited discovery inay be preferable to full discovery or a hearing. For exainple, in $S E C$ v. Dresser Industries, Inc. ${ }^{213}$ the defendant sought discovery to determine whether an agency subpoena had been issued in good faith. The court, noting that "district courts inust be cautious in granting such discovery rights," stated:

Discovery should be permitted only where the respondent is able to distinguish himself from "the class of the ordimary [respondents]", ... by citing special circumstances that raise doubts about the agency's good faith. Even then, district courts must limit discovery to the minimum necessary in the interests of justice by requiring specific imterrogatories or affidavits rather than "full dress discovery and trial."214

Similarly, in Raz Inland Navigation Co. v. ICC, the court considered whether private contacts with the commission chairman constituted improper ex parte contacts. ${ }^{215}$ The court resolved the issue based on affidavits of the various parties, holding that the contact in question did not rise to the level of an improper ex parte contact. ${ }^{216}$ Other courts have permitted full discovery, however, on an appropriate showing of bad faith. ${ }^{217}$

Where neither allegations of noral turpitude nor inquiries into the thought processes of agency officials are involved, the showing required to trigger discovery concerning improper agency action should be less extensive. For example, when private hitigants seek discovery concerning whether governinent agencies have violated procurement regulations in awarding government contracts, courts grant discovery on a virtually routine basis, frequently without any discussion of whether discovery should be permitted. ${ }^{218}$ It inay be that courts recognize that

213. 628 F.2d 1368 (D.C. Cir.), cert. denied, 449 U.S. 993 (1980).

214. Id. at 1388 (footnotes omitted). See also United States v. Marine Midland Bank, 585 F.2d 36 (2d Cir. 1978); United States v. Fensterwald, 553 F.2d 231 (D.C. Cir. 1977); United States v. Wright Motor Co., 536 F.2d 1090 (5th Cir. 1976).

215. 625 F.2d 258 (9th Cir. 1980). In Sierra Club v. Costle, 657 F.2d 298 (D.C. Cir. 1981), the court refused further discovery aimed at investigating a claim of improper ex parte contacts. The court ruled that affdavits concerning the alleged contacts were a sufficient record upon which to base its decision. $657 \mathrm{~F} .2 \mathrm{~d}$ at $391 \mathrm{n} .450$.

216. 625 F.2d at 262. Similarly, the district court in Murphy v. FBI, 490 F. Supp. 1134 (D.D.C. 1980), held that the determination of whether an agency has comphed with a request for documents under the FOIA should be initially considered on the basis of affidavits.

217. See SEC v. Wheeling-Pittsburgh Steel Corp., 482 F. Supp. 555 (W.D. Pa. 1979) (en banc), vacated, 648 F.2d 118 (3d. Cir. 1981).

218. See, e.g., Kentron Hawaii Ltd. v. Warner, 480 F.2d 1166, 1176-77 nn.31-33 (D.C. Cir. 1973); General Elec. Corp. v. Kreps, 456 F. Supp. 468,469 (D.D.C. 1978). 
alleged failures by government officials to comply with procurement regulations imvolve subsidiary factual issues - issues that are often not addressed $\mathrm{m}$ the administrative record. In addition, if it is necessary to develop a factual record concerning the procedures that were followed by the procuring agency, this inquiry need not tread upon the protected areas of the decisionmaker's mental processes. It may be limited to discovery of the specific acts taken by agency officials to comply with the agency's regulations. In some, if depositions of agency decisionmakers are sought im a case mvolving allegations of ethical improprieties, and the danger of excessive imtrusion on the decisionmaking process is real, judicial sensitivity about questioning an agency's "good faith" will ordinarily require a strong showing of impropriety as a precondition to the discovery. By contrast, if factfinding concerning unethical agency conduct can be accomplished without probing the mental processes of decisionmakers, or if the agency impropriety is in the nature of violations of regulations without substantial ethical overtones, a much more limited showing should ordinarily be required. In either case, limitations on the scope or type of discovery or other factinding procedures can serve to alleviate judicial efforts and moderate the level of slowing that courts should require in particular cases. $^{219}$

\section{Discovery of an Agency's Contemporaneous Construction of Relevant Regulations.}

Up to this point the discussion has focussed on areas of permissible factfinding relating to matters collateral to the merits of the agency's decision. Discovery concerning the merits of an agency's decision is generally not permitted because Overton Park requires that disputes on the merits be resolved on the basis of the administrative record. ${ }^{220}$ Courts have permitted discovery, however, concerning one significant aspect of the merits of an agency action - the proper interpretation of applicable regulations or statutes. Specifically, private parties have been permitted to inquire into an agency's prior interpretation of the legal provision at issue in the case.

The basis for permitting this type of discovery derives from the axiom of administrative law that courts should defer to an agency's interpretation of its own regulations and the statute it is empowered to

219. For example, the court can issue guidelines restricting the subjects to be addressed during depositions of agency decisionmakers and expressly preclude questions concerning their mental processes. Alternatively, the court can require, at least initially, discovery through interrogatories or affidavits. In most cases, this latter alternative is probably less efficient and unnecessary.

220. Citizens to Preserve Overton Park, Inc. v. Volpe, 401 U.S. 402, 420 (1971). 
enforce. $^{221}$ In Udall $v$. Tallman ${ }^{222}$ the Supreme Court noted that "[w]hen faced with the problem of statutory construction, this Court shows great deference to the interpretation given the statute by the officers or agency charged with its administration."223 When the construction of an agency regulation, rather than a statute, is at issue, "deference is even inore clearly in order." 224

This principle can be turned against an administrative agency, however, when it seeks to change its official construction of a statute or regulation. If the agency has interpreted its governing law in more than one way, the courts may disregard the new agency interpretation in deference to an interpretation that may have existed since the effective date of a statute. ${ }^{225}$ At the very least, the deference owed to the official interpretation urged by an agency may be diminished if the agency has expressed in the past unany different constructions of a statute or regulation. ${ }^{226}$ Therefore, it is in the interest of any private hitigant to establish that the agency has at some time construed the statute or regulation at issue in a manner that is inconsistent with the agency's position in litigation. This evidence of prior construction can be used to buttress the litigant's own interpretation or, at least, to devalue the deference owed to the agency's current interpretation.

Prior inconsistent interpretations are not, however, always readily apparent. Official agency interpretations appear not only in the form of interpretative rules published in the Federal Register, but also in

221. See 2A C. Sands, Sutherland Statutory Construction $\$ \S 49.01-49.11$ (4th ed. 1972).

222. 380 U.S. 1 (1965).

223. Id. at 16. On this basis, the Court had previously stated that to sustain an agency's interpretation of a statutory term the court "need not find that [the agency's] construction is the only reasonable one, or even that it is the result we would have reached had the question arisen in the first instance in judicial proceedings." Unemployment Compensation Comm'n v. Aragan, 329 U.S. 143, 153 (1946).

224. Udall v. Tallman, 380 U.S. at 16. As the Court once noted:

Since this involves an interpretation of an administrative regulation a court must necessarily look to the administrative construction of the regulation if the meaning of the words used is in doubt. ... [T] he ultimate criterion is the administrative interpretation, which becomes of controlling weight unless it is plainly erroneous or inconsistent with the regulation.

Bowles v. Semmole Rock \& Sand Co., 325 U.S. 410, 413-14 (1945).

225. The Supreine Court has noted that an agency's interpretation is particularly persuasive "when the administrative practice at stake involves a contenporancous construction of a statute by men charged with the responsibility of setting its machinery in motion, of making the parts work efficiently and suoothly while they are yet untried and new." "Power Reactor Dev. Co. v. Electricians, 367 U.S. 396, 408 (1961) (footnote omitted).

226. The Supreme Court has held that the weight to be given an administrative interpretation depends on "the thoroughness evident in its consideration, the validity of its reasoning, its consistency with earlier and later pronouncements, and all of those factors whieh give it power to persuade, if lacking power to control." Skidmore v. Swift \& Co., 323 U.S. 134, 140 (1944). 
countless interpretative bulletins, enforceinent handbooks, informal guidelines, and auditor's opinions, as well as in the actions of individual enforcement personnel in the field. Therefore, to determine what constructions (both formal and informal) the agency has given a regulation or statutory provision, a private litigant may seek discovery of all relevant agency inaterials.

This type of discovery request raises a number of complex issues. The first question is whether in the context of judicial review of agency action any discovery should be permitted at all or whether judicial review should take place solely on the basis of the administrative record. If discovery is permitted, the next issue is how far that discovery should reach into the administrative agency, including the issues of who speaks for the agency and what constitutes prior construction. Finally, once the court has defined the realın of discoverable inaterials, it must determine the appropriate procedures for discovering the agency's prior construction, including inethods to protect valid clainis of agency privilege.

1. Is Any Discovery of Contemporaneous Construction Appropriate? Although conteinporaneous construction has long been considered relevant as an aid in understanding the ineaning of a statute or regulation, it was not until recently that courts began to consider allowing discovery of inaterials concerning such construction. In the past four years, courts increasingly have been faced with broad discovery requests for such materials. A series of energy cases arising under the petroleuin allocation and price control regulations has emerged as the inost significant case law in this area. ${ }^{227}$ In each of these cases, oil companies faced with threatened or actual enforcennent action based on the Department of Energy's interpretation of a regulation attempted to discover whether the Department's interpretation was consistent with previous interpretations by enforceinent personnel.

In Getty Oil Co. v. DOE, 228 the plaintiff sought broad discovery to challenge both the procedural and substantive validity of a Department of Energy (DOE) order requiring Getty to refund alleged overcharges. ${ }^{229}$ On the governinent's inotion for a protective order, the court determined the extent to which additional discovery would be permitted under the primciples of Overton Park, ${ }^{230}$ and specifically au-

227. See text accompanying notes 228-247 infra.

228. [1978] ENERgy MGMT. (CCH) I 9741 (D. Del. May 4, 1978).

229. Getty sued to enjoin enforcement of a Department of Energy (DOE) reinedial order that required Getty to refund alleged overcharges on a petroleum contract. Id. at 9891 .

230. The court first rejected Getty's request for discovery on the merits of the case, concluding that the discovery was directed at essentially adjudicative facts that had already been determined 
thorized discovery concerning contemporaneous construction of the agency's regulations. The court distinguished discovery relating to contemporaneous construction and discovery concerning the factual issues in the Getty case: "As I view it contemporaneous constructions are not adjudicatory facts. They are analogous to legislative history and are designed to aid the Court in deciding questions of law. Consideration of such agency interpretations do not constitute de novo review."231

This principle was expanded in Standard Oil Co. v. DOE,232 which involved two district court decisions that had upheld producers' challenges to the agency's interpretation of petroleuin price control regulations. ${ }^{233}$ Both district courts permitted discovery designed to elicit evidence of inconsistent agency interpretations. On appeal, the government argued that these other interpretations were irrelevant and that the court should rely on the agency's present construction. The court of appeals began by emphasizing that although courts should generally defer to an agency's interpretation, "the weight to be given to an administrative interpretation depends upon 'the thoroughness evident in its consideration, the validity of its reasoning, its consistency with earlier and later pronouncements, and all of those factors which give it power to persuade, if lacking power to control." "234 The court concluded that the agency's imterpretation of its regulation was not entitled to deference because other statements by agency enforcement personnel during the relevant period were inconsistent with the position the agency asserted in litigation. ${ }^{235}$

Although a long line of energy cases has followed these principles and permitted discovery concerning DOE's contemporaneous construction of disputed regulations, ${ }^{236}$ there has been some suggestion in a few recent cases that the courts will not permit the contemporaneous-con-

as part of the record in the proceedings before DOE. Getty was not entitled to de novo review of these findings because the applicable statute did not authorize de novo review and there was no evidence that the agency's factinding procedures were inadequate. Relying on Overton Park, the court held that de novo review is appropriate only when "the agency either has not been authorized to inake the necessary findings or lacks adequate procedures for doing so." Id. at 9892. Thus, the court determined that its review of Getty's substantive claim should be made solely on the basis of the administrative record before the agency.

231. IC. at 9893.

232. 596 F.2d 1029 (Teinp. Emer. Ct. App. 1978).

233. Id at $1055-56$.

234. Id. at 1056 (footnote omitted).

235. Id.

236. See United States v. Exxon Corp., 87 F.R.D. 624 (D.D.C. 1980); Gulf Oil Corp. v. Scllesinger, 465 F. Supp. 913 (E.D. Pa. 1979); Quincy Oil, Inc. v. Federal Energy Administration, 468 F. Supp. 383 (D. Mass 1979), affd, 620 F.2d 890 (Teinp. Einer. Ct. App. 1980); Amoco Prod. Co. v. DOE, 29 Fed. R. Serv. 2 d 402 (D. Del. 1979); Teimeco Oil Co. v. DOE, 475 F. Supp. 299 (D. Del. 1979); Petrolane, Inc. v. DOE, 79 F.R.D. 115 (C.D. Cal. 1978). 
struction doctrine to remaim open-ended. For example, the district court in United States v. Exxon Corp. ${ }^{237}$ granted the requested discovery, but did so on grounds apparently intended to preserve some flexibility for future cases involving dissimilar fact patterns. The court emphasized that it was the agency's proposal to enforce regulations retroactively and proscribe conduct unaddressed by prior regulations that made discovery of contemporaneous-construction evidence particularly appropriate. ${ }^{238}$ The Exxon court also suggested that the need for contemporaneous construction evidence may depend on the extent to which the regulation at issue is made clear and unambiguous by the language of the regulation itself or its legislative history.

Contemporaneous-construction discovery is inost coinpelling when the regulation is ambiguous or silent as to the issue in dispute. ${ }^{239}$ In Gulf Oil Corp. v. Schlesinger ${ }^{240}$ the court specifically relied on the absence of a contemporaneous administrative explanation with the origimal regulation ${ }^{241}$ as a basis for justifying contemporaneous-construction discovery. The court noted that the preamble to the regulations was silent on the interpretation at issue in the litigation, and "[s]ince no contemporaneous administrative explanation of the original regulation exists, the only ineans by which Gulf can deinonstrate the origmal interpretation . . . is through the testimony of the agency officials responsible for formulating and interpreting the regulations at issue." 242

Even if the preamble to a regulation addresses the issue, however, contemporaneous-construction discovery may still be relevant. Regardless of the statements inade at the time the regulation was drafted, the unanner in which the agency enforces the regulation is probative on the ineaning of the regulation, especially when the agency requests the court to defer to its current interpretation of the law. By placing its construction at issue, the agency validates the relevance of evidence concerning its prior interpretations. ${ }^{243}$

237. 87 F.R.D. 624 (D.D.C. 1980).

238. 87 F.R.D. at 633-34. The court's obvious concern about avoiding an overbroad mle reflects an appreciation that the rules governing contemporaneous-construction discovery must be developed carefully. Such discovery may take a substantial amount of time, involve a substantial number of persous, and impose substantial costs on all parties involved.

239. Id. at 635 .

240. 465 F. Supp. 913 (E.D. Pa. 1979).

241. The purpose of a regulation is ordinarily recited in a preamble when the regulation is published in the Federal Register.

242. Id. at 916 (footnote ountted).

243. Litigants may not, however, offer testimony from sources outside an agency concerning their interpretation of a regulation in order to contradict the meaning of a preamble. Wiggens Bros. v. DOE, 667 F.2d 77, 89 (Temp. Emer. Ct. App. 1981). 
When the administrative record already contains substantial information about the agency's contemporaneous construction, there is a competing rationale for limiting contemporaneous-construction discovery. Federal agencies may argue that just as the administrative record need not contain all facts relevant to the merits but only those facts actually considered by the agency, so the administrative record need not contam all facts relevant to contemporaneous construction. At least one court has rejected this contention. In Petrolane, Inc. $v$. $D O E,{ }^{244}$ discovery was granted even though the administrative record contained some discussion of the agency's contemporaneous construction of its regulations. ${ }^{245}$ This holding is consistent with the Getty Oil doctrine that contemporaneous-construction discovery is more analogous to uncovering legislative history than it is to examining the merits of the issues. ${ }^{246}$

To date, all of the conteinporaneous-construction cases have involved DOE regulations. ${ }^{247}$ There are, of course, an almost unlimited number of fact patterns involving other agencies that may trigger the contemporaneous-construction doctrine, and only time will tell whether additional restrictions on the doctrine will be developed once these divergent fact patterns are analyzed.

2. What Constitutes Contemporaneous Construction? There is now comparatively little controversy over whetler contemporaneous-construction discovery is ever available. The extent to which "non-offcial" statements and documents generated by lower-level officials are relevant as evidence of an agency's contemporaneous construction, however, is more troublesome. A discovery request that requires a searcli of thousands of file drawers is burdensome, but is also likely to reveal inconsistencies in the government's interpretation of a regulation or statute. Thus, although some of the early cases on contemporaneous-construction discovery did not specifically address this issue, ${ }^{248}$ in recent cases the most hotly contested issue is the scope of discovery.

For example, in Standard Oil ${ }^{249}$ plaintiffs sought statements by

244. 79 F.R.D. 115 (C.D. Cal. 1978).

245. Id. at 119 .

246. See note 231 supra. In neither Getty Oil nor the two district court cases in Standard Oil was an administrative record filed with the court. Subsequently, the DOE attempted to distinguish these cases, arguing that had there been an administrative record before the court, no further discovery of contemporaneous construction would have been necessary. The court in Petrolane properly rejected this argument as discussed above.

247. In addition, all the cases have involved regulations promulgated pursuant to notice and comment rulemaking procedures.

248. For example, in Petrolane, the court merely ordered production of "statements, internal memorandums, manuals, directives, and the like." 79 F.R.D. at 119.

249. 596 F.2d 1029 (Temp. Emer. Ct. App. 1978). 
Federal Energy Administration (FEA) auditors and lower-level officials in addition to the policy memoranda and other official statements of the agency. The FEA contended that because "only the FEA's General Counsel, his staff and other 'high level policynnakers' had the authority to issue official interpretations of its regulations," the court should ignore the actions of the FEA auditors and otlier lower-level officials during the relevant period. ${ }^{250}$ The court rejected this rigid distinction, however, and concluded that "the statements by the FEA auditors and other lower levcl officials are entitled to weight in determining the thoroughness of the FEA's consideration of its regulations, the validity of its reasoning, and its consistency with earlier and later pronouncements."251

Other courts liave used the language of the Standard Oil case to support the relevance of stateinents inade at all levels of the agency. ${ }^{252}$ For example, in Amoco Production Co. v. DOE, the court stated that "not only opinions and directives in manuals and tlie like, but also explicit imdicators such as the practice of auditors and the reactions of administrators to knowledge of industry practice in applying the regulations have been considered relevant."253 The court explained the relevance of this discovery by noting that

[i]n view of their technical expertise, their exposure to industry practice and problems, and their ongoing responsibility with respect to interpreting the regulations in the course of day-to-day enforcement, "the statements and actions of these administrators have been con-

250. Id. at 1056.

251. Id. The extent to which the court actually relied on lower level opinions is, howevcr, unclear. The opinion does not indicate that the court focused on any opinions of individual auditors, although the court did place some weight on a regulation change notice written by three auditors in the FEA's refinery audit and review program. This notice, although not an individual auditor's opinion, did not rise to the level of an official agency interpretation. Despite the broad language in the Standard Oil case, however, the court did not seen actually to base its opinion on the construction given the regulation by field-level auditors. Id.

Assuming that lower-level stateinents are entitled to weight in determining the extent to which the court should defer to the "official" position of the agency, one may ask whether such statements can be used affirmatively to establish a contemporaneous interpretation, rather than merely to limit the deference owed to the agency's current interpretation. As a practical nnatter, however, this distinction is without inuch substance, at least in the context of discovery cases in which the private litigant is virtually always seeking to contradict the official interpretation proposed by the agency in litigation. Therefore, whether the evidence is being offered affirmatively or merely to rebut the presumption in favor of the agency's interpretation is not likely to be a real issue in most cases.

252. See, e.g., Quincy Oil, Inc. v. Fcderal Energy Administration, 468 F. Supp. 383 (D. Mass. 1979), affd, 620 F.2d 890 (Temp. Emer. Ct. App. 1980); Amoco Prod. Co. v. DOE, 29 Fed. R. Serv. 2d 402 (D. Del. 1979); Tenneco Oil Co. v. DOE, 475 F. Supp. 299 (D. Del. 1979).

253. 29 Fed. R. Serv. $2 d$ at 405. 
sidered significant even in the absence of an approval of their views by the agency, qua agency." 254

The general conclusion that contemporaneous construction at all levels is relevant does not, however, mean that courts accord equal weight to official statements and the actions of imdividual enforcement personnel. The decisions suggest that, although lower-level statements are relevant, courts are reluctant to base their decisions solely on such indicators, and that courts recognize that the probative value of such statements varies. ${ }^{255}$ As a result, not all arguably relevant contemporaneous-construction evidence is discoverable. When ruling on the scope of discovery, courts have balanced the potential value of the evidence against the burden on the agency in obtaining the evidence. For example, in United States v. Exxon the court concluded, without reaching the issue of whether the company may have been entitled to review files at the lowest agency level, that:

[T] here is no hard and fast rule to guide a court in resolving the scope of relevant conteinporaneous construction. Instead, a court must balance the potential relevance of the desired evidence, along with the likelihood of its existence, against the burden incurred by the agency in culling through its files. ${ }^{256}$

Other cases have also limited the scope of plamtiffs' discovery requests on grounds of burden, albeit without articulatimg any general guidelines for balancing the benefits and burdens of discovery. 257 Thus, case law provides only limited guidance concerning discovery of contemporaneous agency construction. Nonetheless, a few principles emerge. First, all final statements and conclusions by agency personnel amount

254. Id. Similarly, in Tenneco Oil Co. v. DOE, 475 F. Supp. 299 (D. Del. 1979), the court held that "[t]he internal memoranda, directives and guidelines generated and disseminated at a variety of levels are proper items of discovery . . . Id. at 318.

In United States v. Exxon Corp., 87 F.R.D. 624 (D.D.C. 1980), the court determined that Exxon was "entitled to discover lower level, non-official agency statements that interpret and apply the applicable regulations." Id. at 630.

255. See United States v. Exxon Corp., 87 F.R.D. 624 (D.D.C. 1980).

256. Id. at 634. The court concluded that Exxon was entitled to discovery of all relevant documents in the case-specific law enforcement files of regional counsel and in the audit files located at DOE's Crude-Producer Audit Division branch offices. Essentially, the court granted all of Exxon's requests with respect to the scope of the search of DOE's files, but did not rule on whether Exxon might lave been entitled to review files at the site offices of the Crude-Producer Audit Division, the lowest level of the division's offices. The court suggested no rationale for this conclusion, nor did it discuss any specific factors on which it rehed in reaching its decision. $I d$. at 635 .

257. For example, in Amoco Prod. Co. v. DOE, 29 Fed. R. Serv. 2d 402 (D. Del. 1979), the court concluded that the scope of the list of designated officials whose files plaintiffs had sought to search was "beyond the point of diminishing returns and I will expect the parties to confer about narrowing it." Id. at 406. The court, without specifying the appropriate scope of the discovery or explaming why the present scope was too broad, wisely left it to the parties to narrow the coverage of plaintifis' discovery request to make it less burdensome for the agency. 
to relevant contemporaneous construction, whether those final conclusions take the form of an official interpretive rule or the final action of a low-level inspector or auditor. ${ }^{258}$ Second, not all evidence of such constructions outweighs the burden that may be entailed in uncovering it. The responsibility for that balance rests with the district court, which must analyze the question in hight of the specific statute or regulation involved, the nature of the agency, and the scope of the required search.

There are certain guidelines that courts should apply in balancing relevance and burden. With respect to relevance, a reviewing court should consider at least four issues. First, the court should determine the extent to which the contemporaneous construction represents the official position of the agency. Although "non-official" statements are relevant, they are not as probative of the agency's interpretation. Second, the court should consider the extent to which the contemporaneous construction apphes to the entire industry or group in question. A determination that applies to only one individual is less authoritative than one that has been applied on a nationwide basis. This factor may overlap somewhat with the first, but they are not coextensive. Third, the court should consider the extent to which the contemporaneous construction concerns the precise issue before the court. The court should be much more willing to impose a significant discovery burden on the government if the discovery relates to a central issue in the case as opposed to a merely peripheral concern. Fourth, the court should consider the extent to which there are already clear and precise indications of the agency's contemporaneous construction. If the agency has issued an exphicit interpretative rule that resolves the issue, then it is unlikely that a massive search for low-level opimions would be justified because sucl a search would be unlikely to reveal a significant contrary interpretation. A number of courts have limited contemporaneousconstruction discovery to the period prior to the issuance of an official imterpretive rule. 259

After assessing the value of the contemporaneous-construction materials that are sought, the court must balance this value agaimst the burden of the search. In assessing this burden, the court should consider a number of other circumstances. First, the court should consider the amount of time and the number of agency personnel it will take to produce the requested information. A search that requires thousands of man-hours is justified only by the most compelling potential benefits.

258. See notes 227-242 supra and accompanying text.

259. E.g., United States v. Exxon Corp., 87 F.R.D. 624, 635 (D.D.C. 1980). 
Second, the court should consider the extent to which the request will interfere with the agency's use of its files and the day to day operation of its business. A search of files used on a daily basis may be more burdensome than a search of retired files in a warehouse. Similarly, the deposition of the agency's chief is more disruptive than the deposition of a lower-level official. Third, the court should consider the extent to which the agency will be subject to repeated requests of this type. For example, a request to the Internal Revenue Service for all auditors' written actions on an issue raised by an individual taxpayer is burdensome not just because of the size of the required search. That type of request is also subject to constant repetition, thereby greatly increasing the burden on the agency.

Finally, in addition to balancing these factors, the court should consider the nature of the evidence that the agency intends to present on the contemporaneous-construction issue. If the agency intends to rely on a substantial history of prior interpretation to support its construction of the regulation, it is in a sense acknowledging the relevance of contrary evidence that may be discovered through agency officials. If the agency does not plan to introduce affirmative evidence of its contemporaneous construction, however, the private litigant nay in some cases be required to make a greater showing that the discovery is likely to produce meaningful results and is not merely a fishing expediton.

\section{Postscript - The Inevitable Questions of Privilege}

When private litigants seek information froin the government beyond that contained in the administrative record, a multitude of privilege questions invariably arise. Once a litigant establishes a basis for obtaining discovery, the agency frequently seeks to withhold the inforination on the ground that it is protected by soine form of privilege. Thus, as a practical matter, private litigants inust penetrate the screen of privilege to obtain additional facts.

\section{A. The Nature of Governmental Privileges.}

In resisting discovery requests, the government may invoke the privileges that are available generally to all hitigants as well as the privileges that are uniquely available to the government. ${ }^{260}$ For example, confidential counınunications between government decisionmakers and government attorneys for the purpose of obtaining legal advice are pro-

260. See MCCoRmick's Handbook on the LAw of Evidence $\$ \$ 107-110$ (E. Cleary $2 d$ ed. 1972). 
tected by the attorney-chent privilege. ${ }^{261}$ In addition, the quahified protection of the work-product doctrine applies to documents prepared by the agency attorney in anticipation of litigation. ${ }^{262}$ As a general rule, the same principles that govern the application of these privileges to private hitigants apply to the government. ${ }^{263}$

In addition to these standard privileges, the government has certain unique privileges. These special privileges include both the constitutionally based "executive privilege" and a common law evidentiary privilege. ${ }^{264}$ The constitutional privilege is the subject of heated debate and is of uncertain validity. The privilege has been invoked by the executive branch to deny disclosure to the courts, the Congress, and the public. ${ }^{265}$ Advocates of the privilege claim that it applies to inforination about foreign relations and military affairs, internal communications between advisers and the President, and investigative reports. ${ }^{266}$ This constitutional privilege, implied from the notion of separation of powers, has received httle judicial support. It is, however, consistent with the historical relationship between Congress and the executive branch. ${ }^{267}$

The common law evidentiary privilege is inuch inore firmly estab-

261. Coastal States Gas Corp. v. DOE, 617 F.2d 854, 862-63 (D.C. Cir. 1980); Mead Data Cent., Inc. v. United States Dep't of Air Force, 566 F.2d 242, 252 (D.C. Cir. 1977).

262. NLRB v. Sears, Roebuck \& Co., 421 U.S. 132, 154 (1975); Bristol-Meyers Co. v. FTC, 598 F.2d 18, 29 (D.C. Cir. 1978); Jordan v. United States Dep't of Justice, 591 F.2d 753, 755 (D.C. Cir. 1978) (en banc).

263. These principles frequently have a special effect, however, when the government is involved. For example, the general rule that the attorney-client privilege applies only when an attorney is providing legal rather than business advice applies to the government as well, but this principle is especially difficult to apply in the governmental situation because it is often difficult to distinguish an attorney's work as a lawyer from his work as a policynuaker within a given agency. See Gulf Oil Corp. v. Schlesinger, 465 F. Supp. 913 (E.D. Pa. 1979).

It is also clear that the confidentiality requirenent applies to the government as well as to private enterprises. Although the precise limits of the maximun distribution beyond which a docuunent is no longer deemed confidential are unclear, it is certain that too widespread a distribution of documents within an agency vitiates claims of attorney-client privilege. Coastal States Gas Corp. v. DOE, 617 F.2d 854, 863 (D.C. Cir. 1980); Coastal Corp. v. Duncan, 86 F.R.D. 514, 521 (D. Del. 1980); United States v. Exxon Corp., 87 F.R.D. 624, 637-38 (D.D.C. 1980).

Fimally, although many government actions are of an enforcement nature and may result in bitigation, not all of these activities are deened to be "in anticipation of litigation" so as to bring then within the work-product doctrine. For example, courts liave held that the Department of Energy's audits of oil producers, although for the purpose of determining conpliance with federal energy regulations (and therefore subject to potential litigation), are not protected as work product prepared in anticipation of litigation. See, e.g., Coastal Corp. v. Duncan, 86 F.R.D. 514, 522 (D. Del. 1980).

264. See McCormick's Handbook on the Law of Evidence $§ 106$ (E. Cleary 2d ed. 1972).

265. Project, Government Information and the Rights of Citizens, 73 MiCH. L. REv. 971, 1016 (1975).

266. Id 1018.

267. Id. 
hished and is of greater significance. ${ }^{268}$ The common law privilege has been applied to foreign affairs and military matters, ${ }^{269}$ to the identity and, perhaps, the statements of informers, ${ }^{270}$ and to police files of ongoing criminal investigations. ${ }^{271}$ The most important aspect of the common law privilege is, lowever, the government's riglit to withhold information concerning a decisionmaker's predecisional deliberations. This privilege for deliberative communications is the most frequently invoked basis for withholding otherwise discoverable information.

This common law privilege arises out of United States v. Morgan, ${ }^{272}$ a case that reached the Supreme Court four times. ${ }^{273}$ In several of the case's appearances before the Court, the Court was asked to consider statements by the agency head concerning the nature of his deliberations prior to the issuance of the challenged order. In Morgan II, the Court leeld that "it [is] not the function of the court to probe the mental processes of the Secretary in reaching his conclusions if he gave the hearmg which the law required."274 In Morgan IV, the Court confirmed this primciple and lield that it was improper to examine the Secretary at length concerning the process by which he reached the conclusions in his order, including the extent of his study of the record and his consultation with subordinates. ${ }^{275}$ The Court concluded that "[j]ust as a judge cannot be subjected to sucl1 a scrutiny . . . so the imtegrity of the administrative process must be equally respected."276

These holdings were later expanded into a general principle of deliberational privilege in Kaiser Aluminum \& Chemical Corp. v. United States. 277 In that case, retired Supreme Court Justice Reed held that the government need not disclose an advisory opinion on imtra-office policy concerning sales of plants to the plaintiff and other purchasers

268. See Note, Discovery of Government Documents and the Official Information Privilege, 76 COLUM. L. Rev. 142 (1976).

269. United States v. Reynolds, 345 U.S. 1 (1953).

270. See Scher v. United States, 305 U.S. 251, 254 (1938); Hurst v. United States, 344 F.2d 327, 328 (9th Cir. 1965). Although Wigmore states that the privilege extends only to the identity of an informer, $8 \mathrm{~J}$. WIGMORE, EvidENCE $\S 2374$ (McNaughton rev. ed. 1961), other courts have held that the privilege covers the informers' statements as well. See MCCormick's HaNDBooK ON THE LAW OF EVIDENCE $§ 111$ (E. Cleary 2d ed. 1972).

271. See Brown v. Thompson, 430 F.2d 1214 (5th Cir. 1970); Kott v. Perini, 283 F. Supp. 1 (N.D. Ohio 1968).

272. Morgan v. Umited States, 298 U.S. 468 (1936) (Morgan I); Morgan v. United States, 304 U.S. 1 (1938) (Morgan II); United States v. Morgan, 307 U.S. 183 (1939) (Morgan III); United States v. Morgan, 313 U.S. 409 (1941) (Morgan IV).

273. See notes 209-12 supra and accompanying text.

274. Morgan v. United States, 304 U.S. 1,18 (1938).

275. United States v. Morgan, 313 U.S. 409, 422 (1941).

276. Id. (citation omitted)

277. 157 F. Supp. 939 (Ct. Cl. 1958). 
because the document was protected under a common law, deliberational, executive privilege. Relying on Morgan IV, Justice Reed concluded that the court should protect "free discussion of prospective operations and policy" and that it is contrary to the public interest to require production of a document that discusses such inatters. 278 Justice Reed concluded that "[t]here is a public policy involved in this claim of privilege for this advisory opinion - the policy of open, frank discussion between subordinate and chief concerning administrative action." 279 Therefore, as a matter of governmental privilege, the court held that the government is exempt from producing otherwise discoverable documents if those docuinents reveal discussion of prospective operations and policy rather than facts and ultiniate conclusions.

The rule announced in Kaiser Aluminum is now universally accepted. 280 As one court recently stated,

It is clear that the government enjoys a privilege for intra-agency memoranda and docuinents that record the deliberative, predecisonal process leading to an agency decision. This privilege protects the 'administrative reasoning process,' ... or those thoughts, ideas, and analyses that encompass the process by which an agency reaches a decision. . . . Disclosure of predecisional documents would injure the consultative process within the government. 281

\section{B. Overcoming the Government's Assertion of Privilege.}

The deliberational-process privilege provides an established basis

278. Id. at $946-47$.

279. Id. at 946.

280. See Renegotiation Bd. v. Grumman Aircraft Eng'r Corp., 421 U.S. 168 (1975); Jordan v. United States Dep't of Justice, 591 F.2d 753 (D.C. Cir. 1978) (en banc); Vaughn v. Rosen, 523 F.2d 1136 (D.C. Cir. 1975); Freeman v. Seligson, 405 F.2d 1326, 1339 (D.C. Cir. 1968); Carl Zeiss Stiftung v. V.E.B. Carl Zeiss Jena, 40 F.R.D. 318 (D.D.C. 1966), affd sub nom. V.E.B. Carl Zeiss Jena v. Clark, 384 F.2d 979 (D.C. Cir.), ccrt. denied, 389 U.S. 952 (1967); C. MCCoRMiCK, HANDBOOK OF THE LAW OF EVIDENCE $\$ \S 106-13$ (2d ed. E. Cleary 1972); 8 J. Wigmore, EVIDENCE $\$ \$ 2367-79$ (McNaughton rev. ed. 1961); 8 C. Wright \& A. Miller, Federal PRACTICE AND Procedure \& 2019 (1970).

281. United States v. Exxon Corp., 87 F.R.D. 624,636 (D.D.C. 1980). The deliberational privilege has two principal policy bases. The first ground, based essentially on relevance principles, is that predecisional analyses or memoranda do not necessarily reflect the basis for the ultimate decision of the agency. As one court recently stated: "documents which are protected by the privilege are those which would inaccurately reflect or prematurely disclose the views of the agency, suggesting as agency position that which is as yet only a personal position." Coastal States Gas Corp. v. DOE, 617 F.2d 854, 866 (D.C. Cir. 1980). The second ground is based on the adverse effect that disclosure of deliberational documents would have on the agency policymaking process. In United States v. Nixon, 418 U.S. 683 (1974), the Suprenie Court noted that "[h]uman experience teaches that those who expect public dissemmation of their remarks may well temper candor with a concern for appearances and for their own interests to the detriment of the decision making process." Id. at 705 . 
for protecting disclosures of government deliberational documents, ${ }^{282}$ but there are instances in which the privilcge nay be overcome. ${ }^{283}$ For example, in Overton Park the Supreme Court stated that "such mquiry into the mental processes of administrative decisionmakers is usually to be avoided," but went on to state that "here there are no . . . formal findings and it may be that the only way there can be effective judicial review is by examining the decision inakers themselves."284 Thus, if the only way a court can determine the basis for the agency's decision is through an examination that may imtrude on mental processes, then the privilege should yield to the extent necessary to permit adequate judicial review of the agency decision. ${ }^{285}$ The district court, however, has broad discretion to fashion the type of additional factfinding that may be necessary to provide an adequate basis for judicial review. ${ }^{286}$ Courts are usually conservative, choosing the method that provides the necessary information while preserving to the greatest extent possible privileged information from discovery. ${ }^{287}$

In addition, not all internal government documents are protected by the deliberational-process privilege. For example, specific facts that do not refiect the decisionmaker's opinion may still be discoverable because the privilege protects only the deliberations and mental processes of an agency's decisionmakers. ${ }^{288}$ Thus, if a document contains predecisional opinions that are within the scope of the privilege, but also contains discoverable facts, a private litigant is entitled to obtain the portion of the document that is not within the scope of the privilege. ${ }^{289}$ Similarly, an agency should not be able to obtam blanket protection against all deposition questioning if there are specific subjects on which a decisionmaker can give factual testimony that would not reveal predecisional opinions.

Serious practical difficulties frequently arise in resolving compet-

282. This privilege has been essentially codified in Exemption 5 to the FOIA, which was intended to formalize the dehberational privilege of the Kaiser Aluminum case. EPA v. Mink, 410 U.S. 73, 86-87 (1973). Several courts have ruled, however, that Exemption 5 cases can serve only as a rough guide for the applicatiou of the common law deliberational privilege to discovery in civil litigation against the government. E.g., Coastal States Gas Corp. v. DOE, 617 F.2d 854 (D.C. Cir. 1980); Amoco Prod. Co. v. DOE, 29 Fed. R. Serv. 2d 402 (D. Del. 1979). The basis for this conclusion is that although the relevance of and need for the requested material are not issues in FOIA cases, they are primcipal elemeuts in the resolution of discovery disputes under the Federal Rules of Civil Procedure.

283. Mobil Oil Corp. v. DOE, 520 F. Supp. 414, 417 (S.D.N.Y. 1981).

284. 401 U.S. at 420.

285. See text accompanying notes $26-42$ supra.

286. Id.

287. E.g., United States v. Exxon Corp. 87 F.R.D. 624 (D.D.C. 1980).

288. See EPA v. Mink, 410 U.S. 73, $85-94$ (1973).

289. Id. 
ing claims regarding the government's assertion of privilege. ${ }^{290}$ For example, a court may have to review thousands of pages of materials in order adequately to assess the government's privilege claim with respect to documents. Although courts are understandably reluctant to accept such an overwhelming burden, it is clear that they may not issue either a blanket grant or a blanket denial of privilege without reviewing the government's claim and at least soine of the documents themselves. ${ }^{291}$ As a result, most courts responding to privilege claims concerning large groups of documents have required the government to list precisely and in detail the basis for its claim. ${ }^{292}$

290. As a preliminary matter, the burden of asserting and proving the existence of a deliberational process privilege (or any other privilege) rests on the government. Coastal States Gas Corp. v. DOE, 617 F.2d 854, 868 (D.C. Cir. 1980). As a general rule, the privilege must be asserted by the head of the agency claiming the protection. Pierson v. United States, 428 F. Supp. 384 (D. Del. 1977) (dicta); $c f$. A. O. Smith Corp. v. FTC, 403 F. Supp. 1000, 1016 (D. Del. 1975) (agency head must assert claim of executive privilege). There is a significant disagreement, lowever, over whether the agency's head nuay delegate the authority to claim the privilege to lower level officials. In Umited States v. Exxon, 87 F.R.D. 624 (D.D.C. 1980), for example, the court stated that "we do not believe that the affidavit need not be sworn by the head of the agency. Instead, it may be sworn by an official, with delegated authority from the Secretary, to assert such representation." Id. at 637 accord, Mobil Oil Corp. v. DOE, 520 F. Supp. 414 (N.D.N.Y. 1981). On the other hand, in Coastal Corp. v. Duncan, 86 F.R.D. 5 I4 (D. Del. 1980), the court refused to permit the assertion of executive privilege by the Economic Regulatory Administration's assistant administrator, even though he had been explicitly delegated the authority to assert evidentiary privileges by the Administrator of the ERA. The court held that because the ERA was a division of the DOE, any assertion of privilege must be made pursuant to guidelines established by the Secretary of Energy. Id. at 517-19. The court einphasized that "the policy interests behind the requirement that the agency head assert the privilege . . . include the need for consistency and careful consideration in the assertion of privilege." 86 F.R.D. at 518. One court lias concluded that the procedural requirement that a responsible official assert the claim may be satisfied as long as the privilege is "raised by mdividuals with specific and detailed knowledge of the documents in which the privilege is asserted." DOE v. Brett, 32 Fed. R. Serv. 2d 911 (Teinp. Emer. Ct. App. 1981). Although arriving at a practical result, the decision does not distinguish two separate points. The cases require specific and detailed knowledge of the documents in order to ensure that the claim is not overbroad. E.g., Mead Data Central, Inc. v. United States Air Force, 466 F.2d 242 (D.C. Cir. 1977). The separate requirement that a responsible official assert the claim, however, is designed to ensure both that the overall claim is based on complete knowledge of the agency's operations and functions and that the agency's position is consistent with its position on other privilege claims. Mobil Oil Corp. v. DOE, 520 F. Supp. 414, 416 (S.D.N.Y. 1981). Thus, although some courts are more lenient than others in permitting delegated authority for the assertion of privilege, it is clear that at the very least, the claim should not be nade by the attorneys in the litigation, but by some responsible official who is able to coordinate the agency's policy concerning the assertion of privilege. When a claim of privilege is asserted during deposition, there slrould be sone indication that the person claiming the privilege is speaking on behalf of the appropriate agency official.

291. In DOE v. Crocker, 629 F.2d 1341 (Temp. Emer. Ct. App. 1980), the court reversed a district court's blanket rejection of the agency's privilege claims on the ground that the district court liad refused to make any in camera review of the docuinents in question. The court required that, at the very least, the trial court must examine samples of representative docunents in order properly to assess the government's privilege claims.

292. E.g., Coastal Corp. v. Duncan, 86 F.R.D. 514 (D. Del. 1980); Teuneco Oil Co. v. DOE, 475 F. Supp. 299 (D. Del. 1979); Pierson v. United States, 428 F. Supp. 384 (D. Del. 1977 ). 
The Court of Appeals for the District of Columbia Circuit has adopted a specific procedure for dealing with government privilege claims concerning large groups of documents. In Vaughn $v$. Rosen ${ }^{293}$ the agency claimed that hundreds of documents requested under the FOIA were privileged. The agency based its assertion of privilege on the agency director's affidavit that merely asserted the privilege in conclusory terms; it contamed no specific information about the documents or their contents. The court concluded that there are two problems with permitting the government to claim privilege on such a limited foundation: first, there is no incentive for the government to disclose marginally privileged documents; and second, the burden of determining the validity of the privilege claim rests entirely on the court without any assistance from the agency in analyzing the documents. ${ }^{294}$ To avoid these problems, the court remanded the case to the district court and ordered the agency to submit an index containing a detailed analysis of each claim of privilege along with a specific listing of every document and the relevant subdivision within the document for which a privilege was claimed.295

The Court of Appeals for the District of Columbia Circuit has subsequently held that this "Vaughn index" must contam "a relatively detailed justification, specifically identifymg the reasons why a particular exemption is relevant and correlating those claims with the particular part of a withheld document to which they apply."296 The court has emphasized that if the burden of preparing the Vaughn index is too great for the governinent, the government must disclose the relevant documents. 297

The Vaughn index has been adopted in non-FOIA cases concerning the deliberational-process privilege. 298 Some courts have also required the government to submit a Vaughn index for claims of attorney-client and work-product privileges. ${ }^{299}$ Thus, although an agency may assert the deliberational-process privilege to prevent discovery of the opmions of its decisionmakers, it must provide substantial factual support for its claims and prepare an extensive and detailed justification for the assertion of the privilege. If the agency does not provide such documentation, courts will probably not accept the

293. 484 F.2d 820 (D.C. Cir. 1973), cert. denied, 415 U.S. 977 (1974).

294. Id. at 826.

295. Id. at 826-27.

296. Mead Data Central, Inc. v. United States Air Force, 466 F.2d 242, 256 (D.C. Cir. 1977).

297. Coastal States Gas Corp. v. DOE, 617 F.2d 854, 858 (D.C. Cir. 1980). See also Cotton

Petroleum Corp. v. Duncan, No. 79-C-217-BT (August 29, N.D. Okla. 1980).

298. See United States v. Exxon, 30 Fed. R. Serv. 2d 179 (D.D.C. 1980).

299. E.g., id. 
agency privilege. ${ }^{300}$ Once the agency provides detailed justification for its claims of privilege, it is incuunbent on the court to review the documents in camera to resolve the privilege dispute. ${ }^{301}$

When the agency asserts privilege claims during depositions, a different set of procedures is required. In most administrative-record cases, depositions are not taken without prior judicial approval. ${ }^{302} \mathrm{Al}-$ though courts are reluctant to anticipate privilege issues in nost civil litigation, im administrative-record cases, in which privilege is likely to be a major issue, courts should consider establishing basic ground rules prior to any depositions. Accordingly, if there are factual questions on which decisionmakers can be examined without intrusion into protected areas, a court should permit the deposition, but clearly delineate the permissible areas of inquiry. If privilege issues nevertheless prove troublesome, a court may use the wide range of sanctions and procedures within its discretion im all civil litigation, mcluding use of a magistrate to supervise the depositions. The court should recognize, however, that because privilege is often asserted with respect to the very thought processes at issue in administrative record cases, active judicial supervision of the discovery process is necessary.

\section{ConClusion}

At the heart of Overton Park is the concept that judicial review of the merits of inforinal agency action should be based on the administrative record. This rule does not, however, preclude discovery and additional factinding on issues other than the factual conclusions reached by agency decisionmakers. The rules for discovery and additional factindimg in administrative-record cases are designed to ensure that courts respect an agency's conclusions on factual and policy issues, but retain adequate ability to review the legal validity and procedural fairness of the agency decision.

As a practical inatter, of course, private litigants use factinding on procedural and legal questions as a weapon to challenge factual conclusions that are generally beyond the reach of further direct question-

300. See notes 297-99 supra and accoinpanying text. In most instances in which the agency fails to provide adequate support for its claim, the court will give the agency another opportunity to prepare adequate documentation. In some instances, however, courts have becoine so irritated at what they perceive to be a willful refusal to respond adequately that they have ordered the government to produce the requested documents immediately. E.g., Coastal Gas Corp. v. Duncan, 86 F.R.D. 514, 522-24 (D. Del. 1980).

301. See DOE v. Crocker, 629 F.2d 1341, 1344-45 (Temp. Emer. Ct. App. 1980); Note, Discovery of Government Documents and the Official Information Privilege, 76 ColuM. L. REv. 142 (1976).

302. See text accompanying notes 71-74 supra and accompanying text. 
ing. This is an inevitable, and in fact desirable, result of the judicial review process. Although the Supreme Court recently held that courts nay not impose procedural requirements of their own on agencies as a means of dictatimg the substance of agency policy, ${ }^{303}$ courts inust continue to evaluate the procedural legality and fairness of agency decisionmaking procedures. In many cases, discovery and additional factinding are useful and necessary elements of the judicial review process.

At the same time, imdependent factfinding in the context of judicial review requires significantly different procedures from those used in most civil hitigation. As a general rule, inuch court involvement is necessary to regulate the length and scope of such additional factfinding. The courts have the obligation consciously to strike the proper balance between adequate judicial review and respect for agency decisions. In most cases, courts should consider imposing a specific discovery plan to guarantee such a balance. ${ }^{304}$ In this way, a court can harness the efforts of the parties to assist it in carrying out its duty to evaluate agency action.

303. See Vermont Yankee Nuclear Power Corp. v. Natural Resources Defcnse Council, Inc., 435 U.S. 519 (1978).

304. Rule 26(f) of the Federal Rules of Civil Procedure specifically permits a judge to adopt such a plan. Fed. R. CIv. P. 26(f). 